NIST

PUBLICATIONS

\section{VENTILATION AND AIR QUALITY INVESTIGATION OF THE MADISON BUILDING PHASE I REPORT}

\section{Andrew K. Persily W. Stuart Dols}

U.S. DEPARTMENT OF COMMERCE National Institute of Standards and Technology National Engineering Laboratory Conter for Building Tochnology Building Environment Division Gaithersburg, MD 20899

Sponsored by:

U.S. Department of Energy Washington, DC
U.S. DEPARTMENT OF COMMERCE Robert A. Mosbacher, Secretary NATIONAL INSTTUTE OF STANDARDS AND TECHNOLOGY

Raymond G. Kammer, Acting Director 
WHOTAL MUSTINUTE OF STALURDS \&

TECHNOLOGY

Research Information Center

Gaithersburg, MD 20899

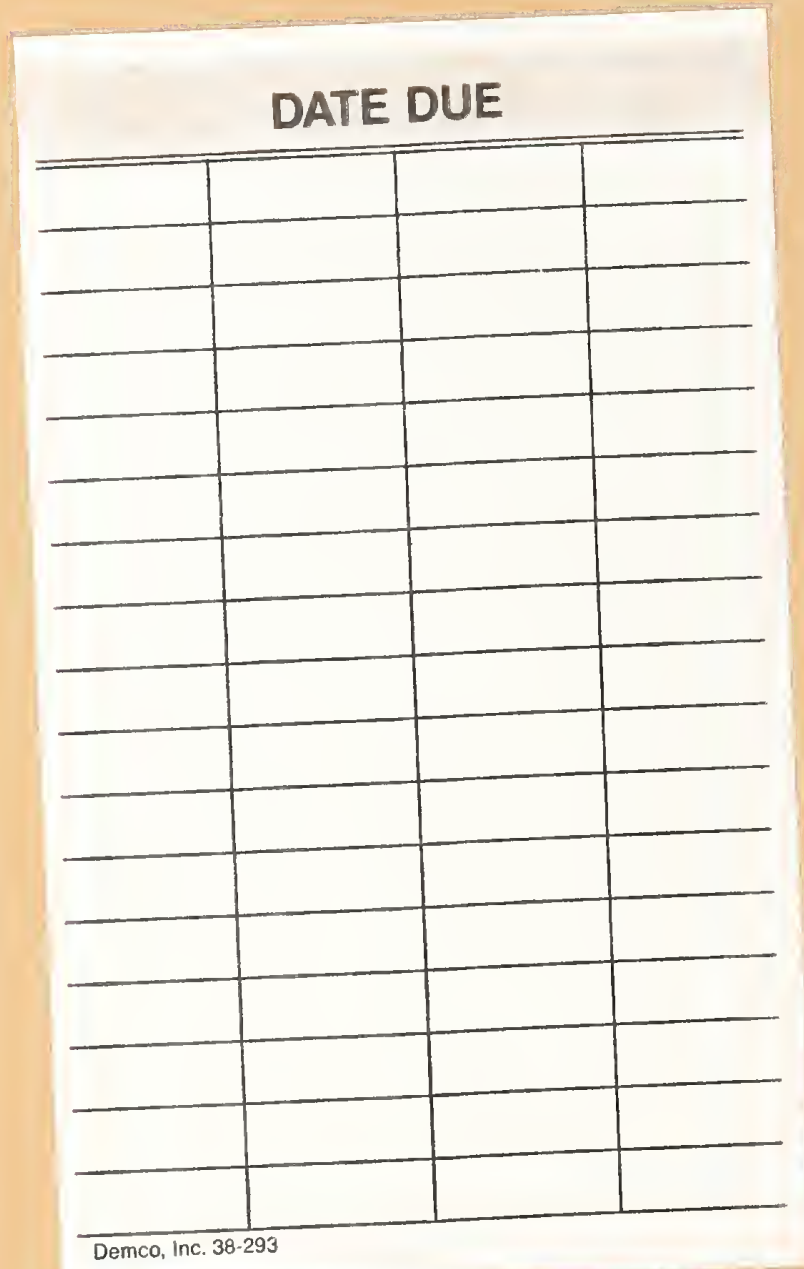




\section{VENTILATION AND AIR QUALITY INVESTIGATION OF THE MADISON BUILDING PHASE I REPORT}

\section{NISTC \\ Q6100 \\ .456 \\ no $89-4219$ \\ 1989 \\ C. 2}

\section{Andrew K. Persilly W. Stuart Dols}

U.S. DEPARTMENT OF COMMERCE National Institute of Standards and Tochnology National Engineoring Laboratory Center for Building Technology Building Environment Division Gaithersburg, MD 20899

Sponsored by: U.S. Department of Energy Washington, DC

December 1989

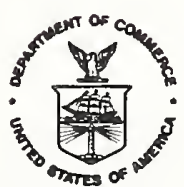

U.S. DEPARTMENT OF COMMERCE Robert A. Mosbacher, Secretary NATIONAL INSTIUUTE OF STANDARDS AND TECHNOLOGY

Raymond G. Kammer, Acting Director 



\section{ABSTRACT}

The National Institute of Standards and Technology (NIST, formerly the National Bureau of Standards) is conducting a long-term study of ventilation and air quality in the Madison Building of the Library of Congress. This investigation, which is being sponsored by the U.S. Department of Energy, began in late 1988 and will continue into 1990. NIST is conducting continuous measurements of whole building air exchange rates, as well as periodic measurements of local ventilation characteristics and indoor levels of carbon dioxide, carbon monoxide, respirable particulates, radon and radon progeny, and volatile organic compounds. During the first phase of the study, NIST has measured whole building air exchange rates, local air exchange characteristics, and indoor concentrations of carbon dioxide and carbon monoxide. This report presents the techniques used to make these measurements and the results that have been obtained as of September 1989. These results indicate that the whole building air exchange rate is relatively constant over time and that the ventilation air is well distributed throughout the building. The measured air exchange rates are slightly above the minimum recommended levels contained in ASHRAE Standard 62-1989 and slightly below the mechanical ventilation system's design value for the outdoor air intake rate. The measured levels of carbon dioxide and carbon monoxide are low relative to the recommended values contained in this same ventilation standard.

Key Words: air exchange, carbon dioxide, indoor air quality, mechanical ventilation, office building, tracer gas, ventilation, ventilation effectiveness 



\section{INTRODUCTION}

The James Madison Memorial Building of the Library of Congress, located in downtown Washington DC, has had a history of indoor air quality complaints by the building occupants. These have included complaints about stale, "dead" and uncomfortable air, poor air circulation, warm temperatures, and physical discomfort such as headaches, drowsiness, nausea, and sinus irritation. In an attempt to determine how these complaints may be related to the ventilation system performance and contaminant concentrations in the building, the Center for Building Technology of the National Institute of Standards and Technology (NIST) is conducting an evaluation of the building's ventilation and air quality characteristics. This evaluation consists of the measurement of building ventilation rates, other ventilation system performance characteristics, and the concentrations of selected indoor air pollutants, followed by the comparison of these measured values to appropriate standards. In addition, the study is designed to investigate how these pollutant levels are related to the building ventilation system operation and performance and the activities occurring in or near the building.

Indoor air quality complaints have become more common, or at least more well publicized, in recent years. Whether or not air quality within office buildings has actually worsened is not known, but the awareness of building occupants and managers with respect to these problems has certainly increased. Although there has been insufficient research to establish the physical causes of many indoor air quality complaints, several reasons have been suggested including the use of materials in buildings that release irritating, if not hazardous, substances and the reduction of building ventilation rates in order to save energy. In fact, the actual ventilation rates that exist in mechanically ventilated office buildings have not been well characterized, and therefore general statements about ventilation rates in existing buildings and trends over time in building ventilation rates can not be supported [Persily 1989].

In fact, indoor air quality problems can and do exist in buildings with adequate ventilation rates for reasons such as poor intake air quality and the existence of interzone airflows that transport contaminants to occupied spaces from areas such as underground garages [Dols and Persily 1989, Grot et al. 1989, Persily et al. 1989]. It is true, however, that inadequate ventilation can not be ruled out as a cause for an indoor air quality problem without making measurements. Ventilation rate measurement and ventilation system performance evaluation are important for determining if a building's mechanical ventilation system is being operated as designed and if the ventilation rates are sufficient according to appropriate standards and guidelines. Despite the obvious importance of ventilation rates in determining indoor contaminant levels, many indoor air quality investigations have not included measurements of ventilation rates and other aspects of building air exchange performance. The investigation of the Madison Building being conducted by NIST includes a ventilation evaluation and contaminant concentration measurement. 
During the NIST investigation, the Madison Building was also the subject of a cooperative study involving EPA, NIOSH, and the Pierce Foundation of Yale University. This cooperative effort involved surveys of occupant perception of the environment and short-term measurements of contaminant concentrations at selected locations within the building. These measurements were made during the week of 27 February 1989. During this week NIST measured whole building air exchange rates and carbon dioxide concentrations, as well as local ventilation characteristics and local carbon dioxide concentrations at selected locations within the occupied space.

\section{BUILDING AND VENTILATION SYSTEM DESCRIPTION}

The Madison Building, the newest of the three Library of Congress buildings, was constructed during the 1970 s and first occupied in 1979. It is a nine-story building with two basement levels and a ground level that is partially below grade. The building contains primarily office space, along with several other facilities including meeting rooms, auditoriums, library material storage areas, a cafeteria and dining rooms on the sixth floor, a snack bar on the ground level, a print shop and preservation laboratory on the ground level, a loading dock on the ground level, and an underground garage that comprises about one-half of the subbasement level. There is a tunnel on the ground floor that connects the Madison Building to the other buildings of the Library of Congress. The total floor area of the building is about $1,770,000 \mathrm{ft} 2$.

The mechanical ventilation system of the Madison Building consists of 44 air handlers in the penthouse mechanical room (located above the sixth floor) and ten additional air handlers in four subbasement mechanical rooms. The penthouse air handlers provide ventilation air predominantly to the upper eight floors of the building, while the air handlers in the subbasement serve only the lower three floors. The portion of the building served by the penthouse air handlers constitutes the bulk of the building volume, while the subbasement air handlers serve only a small fraction of the building volume, most of which is unoccupied.

The Madison Building and the air handling systems are divided into eight zones, as shown in the floor plan schematic in Figure 1. The figure also contains the building column designations. The eight building zones are designated as $A, B, C, D$, $E E, E W, F E$, and FW. Each zone is associated with a bank of air handlers in the penthouse mechanical room and has its own return and supply air shaft. These zones are not isolated from each other in terms of airflow, with interior air being able to flow between these zones through hallways, from room to room, and within open office space that is in more than one zone.

Figure 2 is a schematic of the air handling system for one of the eight building zones. Each zone's system is associated with an outdoor air intake plenum in the penthouse that provides outdoor air to the air handlers serving that zone. Each 
plenum is connected to an outdoor air intake grille located on the roof of the building. There are four to eight air handlers associated with each zone (only three are shown in the figure), with any given air handler serving from one to nine of the building floors. These air handlers all have variable air volume (VAV) supply fans and maintain constant outdoor air intake rates through the control of dampers in the outdoor air intake ducts of each fan. The control of these dampers is based on airflow monitors in the outdoor air intake ducts. The ventilation air from the air handlers is delivered to the occupied space through a network of supply air ducts that run down the building's supply air shafts and through the suspended ceiling plenum on each floor. The return air from the occupied space flows into a plenum above the suspended ceiling system on each floor via return air openings in the suspended ceiling. This return air then flows through the ceiling plenum and into the vertical return air shafts. Each zone's return shaft is connected to a return air plenum in the penthouse (shown in Figure 2) that serves the air handlers for that zone, enabling the recirculation of return air. There are no return fans in the building and no provisions for spilling excess return air, therefore all of the return air is recirculated and the return airflow rate is equal to the supply airflow rate minus the outdoor air intake rate. Any excess of supply airflow over the return airflow leaves the building by exfiltration through leaks in the building envelope and airflow into the ground floor tunnel and local exhaust systems. The air handling systems in the Madison Building operate 24 hours a day, every day of the year. There is a nighttime setback in the supply air static pressure setpoint, but the outdoor air intake rate is constant.

The air handling systems in the Madison Building are somewhat unusual for a modern office building in that the controls are designed to maintain a constant outdoor air intake rate. In addition, outdoor air intake rates are not usually monitored in office building ventilation systems as they are in the Madison Building. The ventilation systems in most office buildings are designed to bring in minimum levels of outdoor air during very cold and very hot weather to reduce the space conditioning load. Large amounts of outdoor air are brought in during mild weather for cooling, employing a socalled economizer cycle. Therefore, in typical office buildings the ventilation rate can vary by a factor of 5 or more depending on the outdoor weather, time of day and season of the year.

Table 1 described the air handlers in the Madison Building. The first column in the table is the air handler designation, and the second column is the supply aifflow rate capacity for each handler in cubic feet per minute (cfm). The design value of the outdoor air intake rate for each air handler is also given in units of cfm and as a percentage of the supply airflow rate. The supply airflow rates are the total capacities of the air handlers, and the actual supply rates will generally be lower in these VAV systems. The percent of outdoor air intake for almost all of the air handlers is $20 \%$ of the supply air capacity.

The total supply airflow rate capacity for the building's air handlers is about 1.8 million cfm, and the total minimum outdoor air intake rate is $362,000 \mathrm{cfm}$. These 
airflow rates can be converted to air changes per hour (ach) by dividing them by the building volume. The gross building volume is equal to the gross floor area of the building multiplied by the ceiling height, including the height of the return air plenum. Using this building volume the supply airflow rate capacity corresponds to about 5 ach, and the design outdoor air intake rate corresponds to 1.05 ach. The actual interior volume of the building is less than this gross volume due to the volume associated with interior partitions, furniture and other items. These airflow rates should therefore be divided by this lower volume, which will increase the corresponding air change rates. An appropriate factor by which to reduce the gross volume is not available, but the correction to the air change rates is probably no more than 10 or $20 \%$.

ASHRAE Standard 62 [ASHRAE 1989] recommends a minimum ventilation rate in office space of $20 \mathrm{cfm}$ per person. This value can be converted to air changes per hour by dividing by the volume associated with a single person. Assuming an occupant density in office space of 7 people per $1000 \mathrm{ft} 2$ (the default value contained in ASHRAE Standard 62), $20 \mathrm{cfm}$ per person converts to about 0.72 ach. This conversion should also be corrected to account for the volume occupied by interior furnishings, but as stated above the correction is probably not large. The outdoor air intake rate specified in the mechanical ventilation system design for this building is almost $50 \%$ above the ASHRAE recommendation. 


\section{MEASUREMENT TECHNIQUES}

There are many factors related to building ventilation and indoor air quality performance, but standardized measurement techniques and procedures are not yet available to study all of them. A standard test method does exist to measure whole building ventilation rates, but not to quantify the uniformity of air distribution or to measure interzone airflow rates in large, mechanically ventilated office buildings. A wide range of indoor contaminants can be measured using equipment and techniques of varying degrees of complexity, but standard protocols do not exist for most contaminants and measurement procedures. Therefore, ventilation and air quality investigations are presently limited in what can be reliably evaluated using accepted measurement procedures.

The first phase of the Madison Building investigation has involved the measurement of whole building air exchange rates, local ventilation characteristics, and indoor pollutant concentrations. The air exchange and local ventilation measurements employed tracer gas techniques, and the concentrations of carbon dioxide and carbon monoxide were measured using infrared absorption monitors.

\subsection{Ventilation Measurements}

Assessing the ventilation characteristics of a building are obviously important in evaluating indoor air quality, but standardized techniques and procedures are available to evaluate only limited aspects of ventilation performance in mechanically ventilated office buildings. As mentioned above, there is a standard test method for measuring whole building air exchange rates, but techniques are still under development to quantify ventilation air distribution and to measure interzone airflow rates. The ventilation assessment of the Madison Building included the measurement of whole building air exchange rates using the tracer gas decay technique and the evaluation of air distribution effectiveness using two proposed methods.

\subsubsection{Whole Building Air Exchange Rates}

Whole building air exchange rates were measured in the Madison Building using the tracer gas decay technique. This procedure has been used in thousands of residential buildings and many office buildings [Persily and Grot 1985a, Persily 1989], and is the subject of an ASTM Standard Test Method [ASTM 1983]. The tracer gas decay technique determines the rate at which outdoor air enters a building, including both intentional outdoor air intake through the air handling systems and unintentional infiltration through leaks in the building envelope. Regardless of common design expectations of minimal infiltration rates in mechanically ventilated office buildings, these two components of air exchange can be comparable in magnitude [Persily and Grot 1985b, Persily and Norford 1987]. The air exchange rate of a building depends on a variety of factors including the design, installation and operation of the 
mechanical ventilation system, the airtightness of the building envelope, the interior configuration of the building, outdoor weather conditions, and the ventilation system controls. Due to the complexity of air exchange in mechanically ventilated buildings, many air exchange rate measurements are required to understand the air exchange characteristics of a building.

In the tracer gas decay technique, a harmless and nonreactive tracer gas is released into a building and mixed thoroughly with the interior air. Once the tracer gas concentration within the building is spatially uniform, the decay in concentration is monitored over time. The rate of decay of the logarithm of concentration is equal to the air exchange rate of the building during the test period, in units of building volumes per unit time (generally air changes per hour, ach). It is crucial that the tracer gas concentration be uniform throughout the building interior during the measurement, such that the concentration within the building can be characterized by a single value. If this condition of uniform concentration is not achieved, then the measurement results are not valid. A uniform tracer gas concentration can be facilitated through tracer gas injection strategies that distribute the tracer throughout the building volume. The mixing of the interior air by the building air handling systems also assists in achieving a uniform tracer gas concentration. The uniformity in concentration must be verified by sampling the concentration at several locations within the building.

The tracer gas measurements of air exchange in the Madison Building employed an automated measuring system that enables the collection of large amounts of data under a range of outdoor weather and building operation conditions. The automated measuring system has been used previously to provide continuous measurements of building air exchange rates [Persily and Grot 1985a] and employs sulfur hexafluoride $\left(\mathrm{SF}_{6}\right)$ as the tracer gas. The microcomputer-based system controls the tracer gas injection and air sampling, records the $\mathrm{SF}_{6}$ concentrations, and monitors and records the outdoor weather, indoor temperature and fan operation status. The $\mathrm{SF}_{6}$ concentrations were measured with a gas chromatograph equipped with an electron capture detector that determines $\mathrm{SF}_{6}$ concentrations in a range of about 5 to 300 parts per billion (ppb) with an accuracy of roughly $1 \%$. Figure 3 is a photograph of the tracer gas measurement system installed in the penthouse mechanical room of the Madison Building.

In tracer gas tests, the manner in which the tracer gas is injected into the building and the locations at which the tracer gas concentrations are measured are necessarily based on the layout of the building and its air handling systems. In the Madison Building both the tracer gas injection and the air sampling strategy are based on the division of the building into the eight zones shown in Figure 1. Tracer gas is injected into the eight outdoor air intake plenums associated with the eight building zones as described below. The $\mathrm{SF}_{6}$ concentration is monitored in each of the eight return air shafts and at an outdoor location. Figure 2 depicts the injection and sampling scheme for an individual air handling zone. A tracer gas injection tube carries a metered amount of tracer gas from the automated system to each of the eight 
outdoor air intake plenums, where the injection tube is connected to an injection manifold containing a flowmeter for each air handler in that zone. A separate injection line runs from the outlet of each flowmeter to each air handler in that zone. Thus, when tracer gas is injected into one of the eight zones, it is released into all the air handlers of that zone for the same length of time, at flow rates that are based on the volume served by each individual air handler. The automated tracer gas decay system injects $\mathrm{SF}_{6}$ into 39 of the 44 penthouse air handlers.

Figure 4 shows a schematic of the $\mathrm{SF}_{6}$ measurement system, along with the $\mathrm{CO} / \mathrm{CO}_{2}$ system discussed later. Air sample tubes of $3 / 8 \mathrm{in}$. outside diameter (OD) polyethylene are connected to a series of air sample pumps which pull air from the air sample locations described above. The output of these pumps is connected to the 10 channel $S F_{6}$ analyzer, which is controlled by the microcomputer-based data acquisition and control system. This system also controls the tracer gas injection system which releases $\mathrm{SF}_{6}$ into the building air handlers through 1/8 in. OD nylon tubing.

During the whole building air exchange measurements, tracer gas is injected into the building air handlers every three hours. The tracer is injected at a rate that is based on achieving an initial concentration of about $150 \mathrm{ppb}$ in the building. After the injection, the tracer gas concentration is monitored at the nine air sample locations, with each location being sampled once every ten minutes. During the measurement period the system monitors and records the outdoor air temperature, the air temperatures in the eight return air shafts, and the fan operation status. In this building, the fans operate 24 hours a day, except during servicing, and the tracer gas testing is conducted continuously with eight decays each day. The tracer gas concentration data is analyzed to determine the decay rate for each of the eight returns, and these eight decay rates are averaged to determine an estimate of the whole building air exchange rate. The accuracy of this air exchange rate determination is a function of the uniformity of tracer gas concentration within the building and is estimated to be about $10 \%$.

Measurements of whole building air exchange rates started during January of 1989 and have continued almost continuously since then. The results as of September 1989 constitute a dataset of about 650 measured air exchange rates along with the corresponding weather and fan operation conditions. Analysis of the measurement results enables the determination of how the building air exchange rates compare to the design ventilation rates and how they are affected by weather, time of day, and season of the year. 


\subsubsection{Local Ventilation Characteristics}

Measured values of whole building air exchange rates can be compared to design rates and ventilation standards, but they do not provide any information on the distribution of this ventilation air to individual locations within a building. Although the ventilation rate may be adequate on a whole building scale, if this air is not well distributed there may be areas within the building with inadequate outdoor air supply. Nonuniformities in air distribution, i.e., rooms or locations within rooms that are less well ventilated than other portions of the building, have been suspected as being responsible for some air quality complaints. There are no accepted measurement techniques for quantifying the uniformity of air distribution or ventilation effectiveness in mechanically ventilated office buildings, and therefore the air quality impacts of nonuniformities in air distribution have not been demonstrated. However, based on the potential importance of air distribution, ventilation effectiveness measurement techniques for field application are being developed and studied [Sandberg 1983, Persily 1985, Persily 1986, Seppanen 1986, Fisk et al. 1988].

Measurements of local air exchange characteristics were performed at 56 locations within the occupied space of the Madison Building during the week of cooperative testing. These local evaluations consisted of measurements of local tracer gas decay rates and mean local ages of air. Although these techniques provide a qualitative indication of ventilation effectiveness, they have not yet been demonstrated to yield reliable measurements of ventilation effectiveness in the field. Their application in the Madison building must be considered in part an investigation of their potential usefulness for studying ventilation effectiveness. These procedures address the distribution of outdoor air within the building but do not deal with other air distribution issues such as thermal comfort and ventilation system aiflow rates.

To measure the local tracer gas decay rate at some location in the building, a series of air samples was collected at that location during a whole building tracer gas decay test. After waiting one hour to allow the tracer gas injection to mix with the interior air, five air samples were collected at roughly 30 minute intervals. The tracer gas concentrations of the air samples were then fit to an equation of the form

$$
C_{i}(t)=C_{0 i} e^{-\lambda_{i} t}
$$

$\mathrm{C}_{i}(t)$ is the concentration at location i measured at time $t$, and $C_{o i}$ and $\lambda_{i}$ are determined from the curve fit. $C_{o i}$ corresponds to the tracer gas concentration at the ith location at $t$ $=0$, and $\lambda_{i}$ is the tracer gas decay rate at the location in units of air changes per hour. Although $\lambda_{i}$ has the units of an air exchange rate, it is not generally equal to the air exchange rate at the location being tested. Based on multi-zone building airflow theory, the tracer gas concentration at all locations in the building will decay according to Equation (1) after a sufficient length of time, assuming that none of the locations are 
totally isolated from the rest of the building. The values of $\lambda_{i}$ will be the same throughout the building, regardless of the degree of mixing within the building [Sinden 1978]. This value of the decay rate $\lambda_{i}$ is not the ventilation rate at any specific location or for the whole building unless the tracer gas concentration is uniform throughout the building being tested, i.e., the distribution of ventilation air is perfect. Each location is therefore characterized by its value of $C_{o i}$. The value of $C_{o i}$ will be higher at locations that are less well ventilated and can be considered an indicator of ventilation effectiveness. There are no straightforward relationships between the values of $C_{o i}$ and the airflow rates within the building except in very simple situations [Sandberg 1981]. In real buildings, these values of $C_{o i}$ can only be used as a qualitative indicator, with higher values corresponding to poorer ventilation effectiveness. There are some practical considerations regarding the use of $\mathrm{C}_{o i}$ as a measure of ventilation effectiveness. If one does not wait long enough before fitting the data to Equation (1) the values of $\lambda_{i}$ will vary among locations and $C_{o i}$ may not be a valid indicator of ventilation effectiveness. Also, variation in the values of $\mathrm{C}_{\mathrm{oi}}$ can exist due to a nonuniform distribution of the initial tracer gas injection.

Measurements of the mean local age of air were also made in the building as a measure of local ventilation characteristics. Mean local age has been proposed for quantifying ventilation effectiveness and has provided useful results in both laboratory and field tests [Sandberg 1983, Seppanen 1986]. However, complications exist when applying the measurement procedures in large, mechanically ventilated office buildings [Persily 1986], and research is needed to examine the applicability of this approach to this building type. Mean local ages were measured at the same 56 locations at which local decay rates were monitored.

The mean local age of air is defined as the average amount of time that has elapsed since the air at some location has entered the building. If the air within a building is perfectly mixed, then the local age will be the same throughout the building and equal to the inverse of the building air exchange rate. If there is nonuniform air distribution within a building, then those locations with poor air distribution will have local ages that are higher than the building average. To measure the mean local age of air, one establishes uniform tracer gas concentration within the building. The local mean age of air at location $i$ is then defined as:

$$
\tau_{i}=\frac{\int_{0} C_{i}(t) d t}{C_{o i}}
$$

The integral in the numerator is evaluated from $t=0$ until the tracer gas concentration is essentially equal to zero. In the Madison Building, the integral was based on an average concentration determined by slowly filling an air sample bag at a constant rate for approximately two hours. The integral was also determined numerically from 
the tracer gas concentrations at each location measured every one-half hour during the local decay rate measurements. The measured values of $\tau_{\mathrm{i}}$ at the various locations within the building can be compared to one another in order to evaluate the uniformity of distribution of ventilation air. The inverse of $\tau_{\mathrm{i}}$, while not equal to a local ventilation rate, can be compared to the whole building air exchange rate.

\subsection{Pollutant Concentration Measurements}

The NIST study of the Madison Building involves the measurement of several indoor contaminants, but only the carbon dioxide and carbon monoxide measurement results are available at this time. While indoor levels of $\mathrm{CO}_{2}$ rarely reach levels of concern within buildings, they are thought to provide an indication of the adequacy of outdoor air ventilation levels [Salisbury 1986]. ASHRAE Standard 62-1989 [ASHRAE 1989] recommends that indoor $\mathrm{CO}_{2}$ levels be maintained below 1000 parts per million (ppm). Carbon monoxide ( $\mathrm{CO}$ ) concentrations were measured to determine whether the air within the building was being contaminated by motor vehicle exhaust from the loading dock, the underground garage, or the outdoor air. ASHRAE Standard 621981 based its recommendation for maximum indoor CO concentrations on the outdoor air requirements in the National Ambient Air Quality Standards [U.S. Environmental Protection Agency], i.e., a maximum average $\mathrm{CO}$ concentration of 35 ppm for one hour and 9 ppm for 8 hours. The 1989 revision of Standard 62 contains no recommendation for indoor $\mathrm{CO}$ concentrations but reports that concentrations above about 26 ppm have been suggested as being of limited concern.

Whole building measurements of carbon dioxide and carbon monoxide concentrations were made using the system depicted in Figure 4. This system was used to determine whole building average concentrations based on air samples from the building's eight return air shafts. Concentrations were also measured at an outdoor location. These measurements employed the same air sample tubes and pumps used in the $\mathrm{SF}_{6}$ decay tests, with a portion of the pump output directed to the $\mathrm{CO} / \mathrm{CO}_{2}$ measurement system. This system employs two infrared absorption analyzers for determining $\mathrm{CO}$ and $\mathrm{CO}_{2}$ concentrations and a microcomputer to control the air sampling and to record the data. $\mathrm{CO}$ and $\mathrm{CO}_{2}$ concentrations are determined at each of the sampling locations once every ten minutes. The $\mathrm{CO}_{2}$ monitor has a range of 0 to 2500 parts per million (ppm) and is accurate to within $+/-0.5 \%$ of full scale. The CO monitor has a range of 0 to $50 \mathrm{ppm}$ and is accurate to within $+1-1 \%$ of full scale.

Local measurements of $\mathrm{CO}_{2}$ concentrations were made during the week of cooperative testing at the same test sites at which local ventilation characteristics were monitored. These evaluations involved measuring the $\mathrm{CO}_{2}$ concentration of the twohour average air sample collected during the measurement of the mean local age of air. These measurement results provide an indication of $\mathrm{CO}_{2}$ concentration within the occupied space as opposed to the readings in the return shafts. 


\section{RESULTS}

This section presents the results of the Madison Building measurements that have been made to date including whole building air exchange rates, local ventilation evaluations and indoor concentrations of carbon dioxide and carbon monoxide.

\subsection{Whole Building Air Exchange Rates}

Whole building air exchange rates were measured in the Madison Building from the end of January through August 1989, with a total of about 650 individual measurements. Figures 5 and 6 are plots of the building air exchange rate versus the indoor-outdoor air temperature difference, measured during the day and night respectively. These data indicate that the building air exchange rates are essentially constant over a wide range of temperature differences. The mean daytime air exchange rate is 0.85 air changes per hour (ach) with a standard deviation of 0.05 ach. The nighttime mean is 0.79 ach with the same standard deviation. These standard deviations are similar in magnitude to the measurement uncertainty. Therefore, the outdoor air intake controls are performing as intended, i.e., the building air exchange rate is constant. There are small variations in the air exchange rate over the year as discussed below. There are also slight variations over the day that may be related to the supply airflow rate. The VAV air handling systems in this building increase the supply airflow rate as the occupied space requires more cooling. As the cooling load and the supply airflow rate build up during the day, the air exchange rate also increases slightly. This effect may be due to a slight static pressure dependence of the outdoor air intake control system. The difference between the day and night air exchange rates may then be due to to the difference in the day and night supply airflow rates caused by the nighttime setback in the supply air static pressure setpoint.

Figure 7 shows the daytime air exchange rates plotted against Julian day, showing slight variations in the ventilation rate over the year. The amount of variation is small relative to the measurement uncertainty of roughly $10 \%$. This figure contains two horizontal lines, one associated with the minimum ventilation recommendation in ASHRAE Standard 62-1989, i.e., $20 \mathrm{cfm}$ per person, which corresponds to an air exchange rate of roughly $0.72 \mathrm{ach}$. The other horizontal line corresponds to the minimum outdoor air intake rate in the building's ventilation system design, which is about 1.05 ach. Both the higher and lower limits may be somewhat low since they are based on gross volumes, uncorrected for the volume occupied by interior furnishings and other items. All of the measured air exchange rates are below the design value and above the ASHRAE recommendation. These air exchange rates are similar in magnitude to those measured in other U.S. office buildings [Persily 1989]. 


\subsection{Local Tracer Gas Decay Rates}

During the week of cooperative testing, NIST made measurements of local tracer gas decay rates and local mean ages of air in the Madison Building. The results of the local decay rate measurements are presented in Table 2. Ten tests were conducted, one in the morning and one in the afternoon on five consecutive days. Each test was done in conjunction with a measurement of the whole building air exchange rate, the results of which are summarized in the first column of the table. These results include the whole building air exchange rate and the initial tracer gas concentration $\mathrm{C}_{0}$ for the building, calculated from a curve fit to the whole building tracer gas concentrations. The second column gives the location at which the local tracer gas decay rates were measured, with the building column designations referring to the floor plan in Figure 1. The third column in the table gives the air handler(s) serving each location. Some of the locations are served by a single air handler, while others are in areas served by more than one air handler. One location, 454/P8, was tested eight times to provide an indication of the repeatability of the test results.

The fourth column in Table 2 contains the initial tracer gas concentration $\mathrm{C}_{\text {oi }}$ calculated from a curve fit to the local tracer gas concentrations and the ratio of this local value of $\mathrm{C}_{o i}$ to the whole building value of $\mathrm{C}_{0}$ for that test. The last column in Table 2 contains the tracer gas decay rate at each location and the ratio of this decay rate to the whole building air exchange rate. According to multi-zone building airflow theory, these tracer gas decay rates should be the same at all locations in the building [Sinden 1978]. The average of the ratio of the local decay rates to the whole building decay rates is 0.99 with a standard deviation of $5 \%$, indicating that the tracer gas decay rate is uniform throughout the building. The variation among the local tracer gas decay rates is similar in magnitude to the uncertainty of these measurements. Given that the local decay rates are essentially uniform throughout the building, a value of the ratio of the local $C_{o i}$ to the whole building $C_{o}$ that is close to 1.0 indicates that there is good ventilation air distribution at this location. The average value of this ratio for all the tests is 0.94 with a standard deviation equal to $9 \%$ of the mean, indicating that outdoor air is well distributed at these particular locations. According to multi-zone building airflow theory, those locations for which the air distribution is poor should have a value of $\mathrm{C}_{\mathrm{oi}}$ that is above the building average. Very few of the locations have values of $\mathrm{C}_{\mathrm{oi}}$ that are above the building average. The significance of the predominance of values below the building value for $\mathrm{C}_{0}$ is not clear, but it and the variation in $\mathrm{C}_{\mathrm{oi}}$ throughout the building is probably due in part to nonuniformities in the initial tracer gas injection.

The eight tests conducted at location 454/P8 provide an indication of the repeatability of the test results. The standard deviation of the values of $\mathrm{C}_{\mathrm{oi}}$ at this location is about $7 \%$ of its mean value and the standard deviation of the ratios of $C_{o i}$ to the building $C_{o}$ is $5 \%$. The standard deviation of the local tracer gas decay rates is about $5 \%$ of its mean value. 


\subsection{Local Mean Age of Air}

Table 3 presents the results of the measurements of local mean age of air at the same locations at which the local tracer gas decay rates were measured. The local mean age of air was determined at each location using two different procedures, and the results are shown in the third and fourth columns of the table. The values in the third column are based on the average tracer gas concentration at each test location determined by filling an air bag at a constant rate during the test. The results in the fourth column were determined from a curve fit to the tracer gas concentrations measured every 30 minutes during the test. The local mean age of air $\tau_{\mathrm{i}}$ has units of hours, and its inverse $1 / \tau_{i}$ is in units of air changes per hour. Although $1 / \tau_{i}$ has the same units as an air exchange rate, it is not equal to the air exchange rate at the test location. The last column in the table is the local tracer gas decay rate at each test location from Table 2. The values of $1 / \tau_{i}$ calculated from the integral of the curve fit to the data are closer to the local decay rates than the values of $1 / \tau_{i}$ determined from the average tracer gas concentrations. If the distribution of the ventilation air in this building were perfectly uniform and the measurement results had no errors, then the local mean age of air would be the same throughout the building and its inverse would be equal to the whole building air exchange rate. Any deviations are either indications of nonuniform ventilation air distribution or measurement error. Table 4 lists the average values of $\tau_{i}, 1 / \tau_{i}$ and the local tracer gas decay rates for each of the ten tests and for all the tests together. In all of the tests the variation of the individual measurements of $\tau_{i}$ are only 1 to $8 \%$ of their mean values. The small variation in the values of $\tau_{\mathrm{i}}$ indicates that the distribution of outdoor air to these locations is good, but because there is little experience with this measurement technique the magnitude of these deviations can not be reliably related to the uniformity of air distribution.

The eight tests conducted at location 454/P8 provide an indication of the repeatability of the test results. The standard deviation of $\tau_{i}$ at this location is $7 \%$ of its mean value when determined from the average concentrations and $6 \%$ when determined numerically. Therefore, the variation in $\tau_{i}$ at this location is similar in magnitude to the variation among the different locations in the building. 


\subsection{Contaminant Measurements}

As of the end of Phase I of the Madison Building study by NIST, the indoor levels of carbon dioxide and carbon monoxide have been measured. This section presents the results of the automated measurements of whole building carbon dioxide and carbon monoxide concentrations and the short term measurements of local carbon dioxide concentrations.

\subsubsection{Carbon Dioxide}

Whole-building carbon dioxide $\left(\mathrm{CO}_{2}\right)$ concentrations were measured from the end of February through September 1989 using the automated system described earlier. This measuring system monitored and recorded the $\mathrm{CO}_{2}$ concentrations in the eight building return air shafts and at an outdoor sampling location 24 hours a day, with each location being sampled once every ten minutes. During these measurements the building air exchange rate was monitored with the tracer gas system. An example of the $\mathrm{CO}_{2}$ data are shown in Figure 8 in which the building average and the outdoor $\mathrm{CO}_{2}$ concentrations are plotted against time for five days, the last two days being the weekend. During the week, the indoor $\mathrm{CO}_{2}$ concentration increases when the building occupants arrive, reaching a peak in the late morning. There is a slight decrease in the middle of the day, due to decreased occupancy during lunch, followed by a second peak in the afternoon. When the occupants leave at the end of the working day, the concentration decreases to the outdoor level. During the weekend, when building occupancy is very low, the indoor concentration tracks the outdoor concentration. The variation in outdoor $\mathrm{CO}_{2}$ levels is driven by the photosynthetic activity of plants. During the day, the $\mathrm{CO}_{2}$ concentration is at a minimum because plants are using the available $\mathrm{CO}_{2}$ for photosynthesis. When the sun sets, the plant activity decreases and the outdoor $\mathrm{CO}_{2}$ level increases as the air in the building's vicinity is mixed with air at a higher $\mathrm{CO}_{2}$ concentration from elsewhere in the atmosphere. When the sun rises the next morning, the plants resume their photosynthetic activity and the outdoor $\mathrm{CO}_{2}$ level decreases. Variation in the outdoor $\mathrm{CO}_{2}$ level among individual days is due in part to weather differences affecting the activity of the plants. Outdoor $\mathrm{CO}_{2}$ concentration data collected during the winter exhibit a relatively flat concentration profile due to the inactivity of plants. The variation in indoor $\mathrm{CO}_{2}$ concentration in Figure 8 is typical of a building occupied during the day.

The daily maxima of the whole building $\mathrm{CO}_{2}$ concentrations were determined for each working day in the Madison Building. The average value of the daily peak concentration was $501 \mathrm{ppm}$, the standard deviation was $20 \mathrm{ppm}$, and the largest value for a daily peak was 545 ppm. ASHRAE Standard 62-1989 recommends that the $\mathrm{CO}_{2}$ concentration be maintained below 1000 ppm, and therefore the whole building average $\mathrm{CO}_{2}$ concentrations in the Madison Building are well below the ASHRAE 
maximum.

Two hour averages of the $\mathrm{CO}_{2}$ concentration were measured at the same 56 locations which were evaluated in the local ventilation characterizations. The results of these measurements are shown in Table 5. The first column identifies the test day, the averaging time, and the average $\mathrm{CO}_{2}$ concentration for the whole building obtained from the automated measuring system. The third column of the table lists the average $\mathrm{CO}_{2}$ concentration at each of the locations listed in the second column. The last column lists the ratio of the local concentrations to the building concentration. The average of the local $\mathrm{CO}_{2}$ concentrations is $521 \mathrm{ppm}$, well below the ASHRAE maximum. The maximum value of the local concentration is $593 \mathrm{ppm}$. On average, the local concentrations are $6 \%$ above the whole building average concentrations, presumably due to the fact that the whole building concentrations are influenced by lightly occupied spaces such as hallways.

Both the whole building and the local measurements of $\mathrm{CO}_{2}$ concentration are well below the maximum concentration recommendation in ASHRAE Standard 62, indicating that the ventilation of this building is adequate relative to the number of occupants. This conclusion is in agreement with the results of the measurements of the building's air exchange rates. In any building with a constant level of occupancy, the daily maximum in the $\mathrm{CO}_{2}$ concentration will be related to the building air exchange rate. This relation between $\mathrm{CO}_{2}$ concentrations and air exchange rates has been discussed previously [Persily et al. 1990]. This reference contains a plot of daily maximum $\mathrm{CO}_{2}$ concentration versus daily average air exchange rate for three mechanically ventilated office buildings. This plot is reproduced in Figure 9 with the addition of the Madison Building data. The solid line in the figure is the equilibrium $\mathrm{CO}_{2}$ concentration as a function of air exchange rate based on the following assumptions: an occupant density of seven people per $1000 \mathrm{ft} 2$ of floor area, a ceiling height of about $12 \mathrm{ft}$ (including the return air plenum), an outdoor $\mathrm{CO}_{2}$ concentration of $300 \mathrm{ppm}$, and a $\mathrm{CO}_{2}$ generation rate of $0.011 \mathrm{cfm}$ per person. The data in the figure deviate from the equilibrium curve because the $\mathrm{CO}_{2}$ concentrations in these buildings do not attain equilibrium. Equilibrium conditions are not attained because the $\mathrm{CO}_{2}$ generation rates (occupancy levels) are not constant for long enough periods of time. The deviations between the measured peak $\mathrm{CO}_{2}$ levels and the calculated equilibrium levels are greater at lower air exchange rates because it takes longer to reach equilibrium at lower air exchange rates. These data indicate the inappropriateness of using $\mathrm{CO}_{2}$ concentrations to determine building air exchange rates. The Madison Building data are clustered together in this plot and are consistent with the data from the other buildings, indicating that the relation between $\mathrm{CO}_{2}$ concentrations and air exchange rates in the Madison Building is similar to that observed in other office buildings. 


\subsubsection{Carbon Monoxide}

Whole building average carbon monoxide (CO) concentrations have been monitored in the Madison Building with the automated system. These measurements took place during July, August and September of 1989, and as in the case of $\mathrm{CO}_{2}$ were based on the average of the concentrations in the eight return shafts. The measured CO concentrations in the Madison Building are very low, at the most 1 or 2 $\mathrm{ppm}$. The indoor $\mathrm{CO}$ concentrations appear to track the outdoor levels, which increase in the early morning presumably due to motor vehicle exhaust and decrease late in the day. The increase in outdoor concentration is also on the order of 1 or $2 \mathrm{ppm}$ during the work week. On Saturday and Sunday, no increase in outdoor or indoor CO concentration was observed. The National Ambient Air Quality Standards contain a maximum for an eight-hour average CO concentration of 9 ppm. ASHRAE Standard 62-1989 contains no recommendation for maximum CO levels, but reports that concentrations of $26 \mathrm{ppm}$ have been suggested as a level of concern. Therefore, the whole building average CO concentrations that have been measured by NIST are low compared with the values in these standards. 


\section{REPRESENTATIVENESS OF TEST WEEK}

The long term measurements of whole building air exchange rates and $\mathrm{CO}_{2}$ concentrations in the Madison Building enable the determination of whether the building ventilation rates measured during the week of cooperative testing (27 February through 3 March 1989) were typical for the building. The air exchange rates in Figure 7 exhibit variations over the year, but as discussed earlier the variations are not very large relative to the $10 \%$ measurement uncertainty. Table 6 lists weekly average air exchange rates over the Phase I testing of the Madison Building. These averages are based on the air exchange rates measured during the occupied hours of each week, from Monday through Friday. Based on the $10 \%$ measurement uncertainty in the individual air exchange rates, these weekly averages have an uncertainty of about $+/-0.03$ air changes per hour. Therefore, the weekly average air exchange rate during the test week is only slightly higher than the average of the weeks preceding the test week and no different from the following weeks. The table also lists averages of daily peak $\mathrm{CO}_{2}$ concentrations for the working days of each week, and no significant differences exist between the test week average and the other weeks in the table. Therefore, the whole building air exchange rates and the building average $\mathrm{CO}_{2}$ concentrations during the test week were not significantly different from the conditions in the building during other weeks of the Phase I testing.

\section{SUMMARY}

Phase I of the Madison Building study has included the measurement of whole building air exchange rates over a period of about eight months, the application of two techniques to evaluate the uniformity of air distribution or ventilation effectiveness, the measurement of building average concentrations of carbon dioxide and carbon monoxide, and the determination of local carbon dioxide concentrations. The whole building air exchange rates measured during the day had an average value of 0.85 air changes per hour (ach) with very little variation over the day or over the eight months of measurement. The air exchange rates measured at night were slightly lower. The daytime value is above the ventilation recommendation in ASHRAE Standard 62-1989 (about 0.72 ach) and below the the design air exchange rate for the building (about 1.05 ach). The results of the measurements of local ventilation characteristics, local tracer gas decay rate and mean local age of air, are consistent with good distribution of the outdoor air by the ventilation system. The applicability of these measurement techniques in mechanically ventilated office buildings is not yet well established, and therefore these results must be considered preliminary.

The measurements of whole building average $\mathrm{CO}_{2}$ concentrations yielded an average value of the daily peak concentration of $501 \mathrm{ppm}$ on working days, well below the recommended maximum in ASHRAE Standard 62-1989 of $1000 \mathrm{ppm}$. The local $\mathrm{CO}_{2}$ concentrations were slightly higher than the whole building averages. The whole 
building measurements of carbon monoxide were at most 1 or $2 \mathrm{ppm}$ during working days, and appeared to be driven by the outdoor concentration. The indoor CO levels were well below the National Ambient Air Quality Standards and the level of concern reported in ASHRAE Standard 62-1989.

The measurement results from the Phase I testing of the Madison Building indicate that the building ventilation rates are adequate and the measured contaminant levels are low, and therefore do not serve to identify the sources of the indoor air quality complaints within the building. It must be pointed out that indoor air quality is a complex issue with many factors to consider and that the Phase I measurements address only a limited number of these factors. There are other aspects of ventilation and air quality that could be related to the occupant complaints in the building but were not evaluated in these measurements. Additional measurements of indoor contaminant levels and other aspects of ventilation system performance are being conducted in the Madison Building by NIST in order to more thoroughly assess the indoor air quality of the building. 


\section{REFERENCES}

ASHRAE, 1989, "Ventilation for Acceptable Indoor Air Quality," Standard 62-1989, American Society of Heating, Refrigerating, and Air-Conditioning Engineers, Inc.

ASTM, 1983, "Standard Test Method for Determining Air Leakage Rate by Tracer Dilution," E741, American Society for Testing and Materials.

Dols, W.S., A.K. Persily, 1989, "Ventilation and Air Quality Investigation of the U.S. Geological Survey Building," NISTIR 89-4126, National Institute of Standards and Technology.

Fisk, W.J., R.J. Prill, O. Seppanen, 1988, "Commercial Building Ventilation Measurements Using Multiple Tracer Gases," Proceedings of 9th AlVC Conference Effective Ventilation, Gent, Belgium.

Grot, R.A., A.K. Persily, A.T. Hodgson, J.M. Daisey, 1989, "Environmental Evaluation of the Portland East Federal Building Preoccupancy and Early Occupancy Results," NISTIR 89-4066, National Institute of Standards and Technology.

Persily, A.K., 1989, "Ventilation Rates in Office Buildings," Proceedings of ASHBAE IAQ '89 The Human Equation: Health and Comfort, San Diego.

Persily, A.K., 1986, "Ventilation Effectiveness Measurements in an Office Building," Proceedings of the ASHRAE Conference IAQ '86 Managing Indoor Air for Health and Energy Conservation, Atlanta.

Persily, A.K., 1985, "Ventilation Effectiveness in Mechanically Ventilated Office Buildings," NBSIR 853208, National Bureau of Standards.

Persily, A.K., W.S. Dols, 1990, "The Relation of Carbon Dioxide Concentration to Office Building Ventilation," Air Change Rate and Airtightness in Buildings, ASTM STP 1067, M.H. Sherman, Ed., American Society for Testing and Materials, Philadelphia.

Persily, A.K., W.S. Dols, S.J. Nabinger, D.A. VanBronkhorst, 1989, "Air Quality Investigation in the NIH Radiation Oncology Branch," NISTIR 89-4145, National Institute of Standards and Technology.

Persily, A.K. R.A. Grot, 1985a, "Ventilation Measurements in Large Office Buildings," ASHRAE Iransactions, Vol. 91, Part 2.

Persily, A.K. R.A. Grot, 1985b, "The Airtightness of Office Building Envelopes," Proceedinas of the ASHRAE/DOE/BTECC Conference on the Thermal Performance of the Exterior Envelopes of Buildings III, Clearwater Beach, Florida.

Persily, A.K. L.N. Norford, 1987, "Simultaneous Measurements of Infiltration and Intake in an Office Building," ASHRAE Transactions, Vol. 93, Part 2.

Sandberg, M., 1981, "What is Ventilation Effectiveness?," Building and Environment, Vol.16, No.2.

Sandberg, M., 1983, "Ventilation Efficiency as a Guide to Design," ASHRAE Transactions, Vol. 89, Part 2.

Seppanen, O., 1986, "Ventilation Efficiency in Practice," Proceedings of the ASHRAE Conference IAO '86 Managing Indoor Air for Health and Eneray Conservation, Atlanta.

Sinden, F.W., 1978, "Multi-Chamber Theory of Air Infiltration," Building and Environment, Vol.13. 


\section{Table 1 Mechanical Ventilation System Design Airflow Rates}

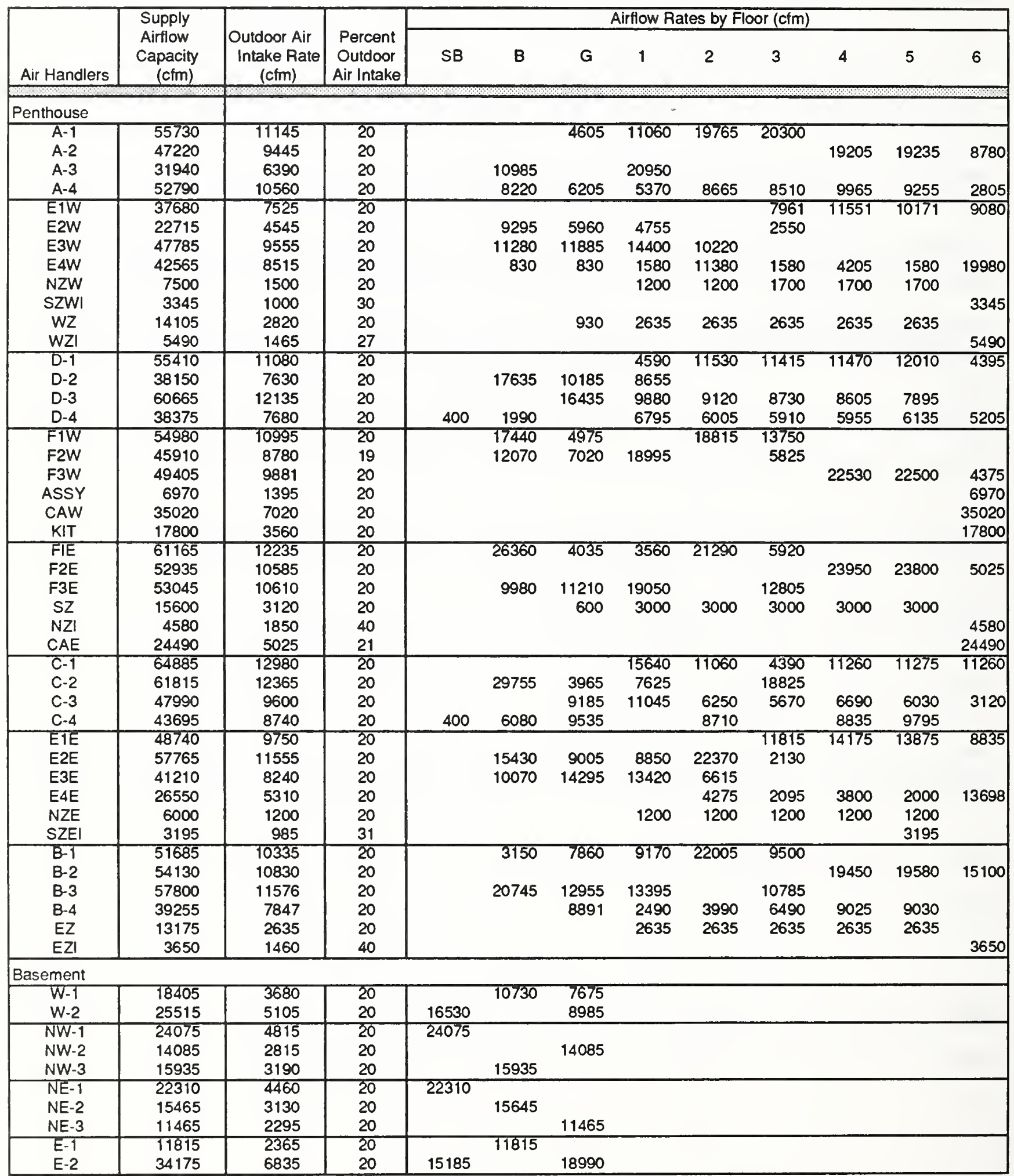


Table 2 Local Tracer Gas Decay Rates

\begin{tabular}{|c|c|c|c|c|c|c|c|}
\hline TEST & & $\begin{array}{c}\text { Room Number/ } \\
\text { Column Location }\end{array}$ & Air Handler & Coi & $\frac{\text { Coi }}{\text { Building co }}$ & $\begin{array}{l}\text { Local Tracer } \\
\text { Gas Decay } \\
\text { Rate (ach) }\end{array}$ & $\frac{\text { Local ach }}{\text { Building ach }}$ \\
\hline \multirow{2}{*}{\multicolumn{2}{|c|}{ Monday-AM }} & $554 / M 8$ & ETW/ETE & 178 & 1.09 & 0.96 & 1.03 \\
\hline & & 616/F12 & D4/D1 & 175 & 1.07 & 0.98 & 1.05 \\
\hline Building Air & & $630 / N 14$ & C1 & 155 & 0.95 & 0.93 & 1.00 \\
\hline Exchange Rate $=$ & 0.93 ach & $630 / N 16$ & C1 & 154 & 0.94 & 0.91 & 0.98 \\
\hline Building $\mathrm{Co}=$ & $164 \mathrm{ppb}$ & $642 / \cup 4$ & B2 & 141 & 0.86 & 0.90 & 0.97 \\
\hline \multirow[t]{4}{*}{ Monday-PM } & & $301 / \mathrm{M} 5$ & E1W & 138 & 0.86 & 0.77 & 0.85 \\
\hline & & 311/D8 & A1 $/ W Z$ & 129 & 0.80 & 0.87 & 0.96 \\
\hline & & 313/D10 & $A 1 / W Z$ & 139 & 0.86 & 0.89 & 0.98 \\
\hline & & $320 / D 14$ & D3 WZ & 156 & 0.97 & 0.93 & 1.02 \\
\hline Building Air & & 325/L17 & F1W & 153 & 0.95 & 0.97 & 1.07 \\
\hline Exchange Rate $=$ & $0.91 \mathrm{ach}$ & $329 / 716$ & $\mathrm{C} 2$ & 155 & 0.96 & 0.95 & 1.04 \\
\hline Building $\mathrm{Co}=$ & $161 \mathrm{ppb}$ & $454 / \mathrm{PB}$ & E1E & 169 & 1.05 & 0.92 & 1.01 \\
\hline \multirow[t]{4}{*}{ Tuesday-AM } & & $301 / M 5$ & EIW & 165 & 1.02 & 0.95 & 1.01 \\
\hline & & $454 / P 8$ & E1E & 173 & 1.07 & 0.97 & 1.03 \\
\hline & & $503 / K 4$ & E1W & 157 & 0.97 & 0.90 & 0.96 \\
\hline & & $509 / D 4$ & A2 & 139 & 0.86 & 0.89 & 0.95 \\
\hline Building Air & & $509 / D 6$ & A2 & 143 & 0.92 & 0.88 & 0.94 \\
\hline Exchange Rate $=$ & $0.94 \mathrm{ach}$ & $548 / S 4$ & B4 & 151 & 0.87 & 0.94 & 1.00 \\
\hline Building $\mathrm{Co}=$ & $162 \mathrm{ppb}$ & $548 / \cup 4$ & B2/B4 & 138 & 0.95 & 0.93 & 0.99 \\
\hline \multirow[t]{4}{*}{ Tuesday-PM } & & $454 / P 8$ & ETE & 170 & 1.09 & 0.96 & 1.02 \\
\hline & & $502 / K 8$ & E1W & 155 & 0.99 & 0.93 & 0.99 \\
\hline & & $524 / K 12$ & F3W & 130 & 0.83 & 0.98 & 1.04 \\
\hline & & 532/R13 & F2E & 157 & 1.01 & 0.99 & 1.05 \\
\hline Building Air & & $537 / N 14$ & $\mathrm{C} 4$ & 140 & 0.90 & 0.93 & 0.99 \\
\hline Exchange Rate $=$ & $0.94 \mathrm{ach}$ & $554 / \mathrm{M} 8$ & E1W/E1E & 156 & 1.00 & 0.95 & 1.01 \\
\hline Building $\mathrm{Co}=$ & $156 \mathrm{ppb}$ & 557/Q10 & F2E/E1E & 156 & 1.00 & 0.97 & 1.03 \\
\hline \multirow[t]{4}{*}{ Wednesday-AM } & & $413 / 010$ & A2/D4 & 144 & 0.95 & 0.96 & 1.05 \\
\hline & & $442 / 512$ & $\mathrm{~F} 2 \mathrm{E} / \mathrm{C} 1$ & 155 & 1.02 & 0.97 & 1.07 \\
\hline & & 444/R10 & $\mathrm{E} 1 \mathrm{E} / \mathrm{B} 1 / \mathrm{F} 2 \mathrm{E}$ & 146 & 0.96 & 0.92 & 1.01 \\
\hline & & 454/P8 & E1E & 153 & 1.01 & 0.87 & 0.96 \\
\hline Building Air & & 454/R8 & B1/E1E & 147 & 0.97 & 0.84 & 0.92 \\
\hline Exchange Rate $=$ & 0.91 ach & 462/P10 & E1E/F2E & 152 & 1.00 & 0.92 & 1.01 \\
\hline & $152 \mathrm{ppb}$ & 464/P12 & F2E & 146 & 0.96 & 0.92 & 1.01 \\
\hline \multirow{4}{*}{ Wednesday-PM } & & $401 / \mathrm{M} 5$ & EIWIETE & 159 & 1.00 & 0.91 & 0.97 \\
\hline & & $405 / J 4$ & $\mathrm{~A} 4 / \mathrm{E} 1 \mathrm{~W}$ & 141 & 0.89 & 0.87 & 0.93 \\
\hline & & $443 N W 11$ & C3/EZ & 140 & 0.88 & 0.90 & 0.96 \\
\hline & & $447 \mathrm{WB}$ & $B 2 / E Z$ & 120 & 0.75 & 0.88 & 0.94 \\
\hline Building Air & & $449 / W 4$ & B2 & 136 & 0.86 & 0.90 & 0.96 \\
\hline Exchange Rate $=$ & $0.94 \mathrm{ach}$ & 449 W5 & $\mathrm{B} 2$ & 133 & 0.84 & 0.91 & 0.97 \\
\hline Building $\mathrm{Co}=$ & $159 \mathrm{ppb}$ & 454/P8 & E1E & 169 & 1.06 & 0.93 & 0.99 \\
\hline \multicolumn{2}{|l|}{ Thursday-AM } & 119/H17 & D2JFW & 155 & 3.03 & 0.92 & 3.02 \\
\hline Building Air & & 135/W8 & $\mathrm{B} 1 / \mathrm{EZ}$ & 127 & 0.85 & 0.86 & 0.96 \\
\hline Exchange Rate $=$ & 0.90 ach & $138 / \times 5$ & B3 & 126 & 0.84 & 0.86 & 0.96 \\
\hline Building $\mathrm{Co}=$ & $150 \mathrm{ppb}$ & 454/P8 & E1E & 153 & 1.02 & 0.88 & 0.98 \\
\hline \multirow[t]{4}{*}{ Thursday-PM } & & $309 / G 5$ & $\overline{A 4}$ & 143 & 0.89 & 0.84 & 0.93 \\
\hline & & $311 / \mathrm{E} 9$ & A1 & 125 & 0.78 & 0.86 & 0.96 \\
\hline & & $320 / G 17$ & D1 & 165 & 1.03 & 0.95 & 1.06 \\
\hline & & 324/G11 & D1 & 149 & 0.93 & 0.93 & 1.03 \\
\hline Building Air & & $331 / \pi 17$ & $\mathrm{C} 2$ & 150 & 0.94 & 0.91 & 1.01 \\
\hline Exchange Rate $=$ & $0.90 \mathrm{ach}$ & 409/E7 & A2 & 145 & 0.91 & 0.89 & 0.99 \\
\hline Building $\mathrm{Co}=$ & $160 \mathrm{ppb}$ & 454/P8 & E1E & 158 & 0.99 & 0.83 & 0.92 \\
\hline \multirow[t]{3}{*}{ Friday-AM } & & $105 / \mathrm{K} 4$ & $E 3 W$ & 160 & 1.09 & 0.91 & 0.99 \\
\hline & & 209/E7 & A1 & 116 & 0.79 & 0.85 & 0.92 \\
\hline & & 209/D4 & A1 & 116 & 0.79 & 0.82 & 0.89 \\
\hline Exchange Rate = & $0.92 \mathrm{ach}$ & $235 / N 10$ & $\mathrm{~B} 1 / \mathrm{C} 3$ & 130 & 0.88 & 0.92 & 1.00 \\
\hline Building $\mathrm{Co}=$ & $147 \mathrm{ppb}$ & 454/P8 & E1E & 143 & 0.97 & 0.90 & 0.98 \\
\hline \multirow[t]{4}{*}{ Friday-PM } & & 215/E12 & D4 & 154 & 0.99 & 0.98 & 1.05 \\
\hline & & $219 / C 16$ & D3 & 148 & 0.95 & 0.98 & 1.05 \\
\hline & & 219/E 18 & D3/D1 & 153 & 0.98 & 0.97 & 1.04 \\
\hline & & $221 / G 16$ & D1 & 154 & 0.99 & 0.95 & 1.02 \\
\hline Building Air & & $222 / K 14$ & Fiw & 164 & 1.05 & 1.03 & 1.11 \\
\hline Exchange Rate $=$ & $0.93 \mathrm{ach}$ & 227/P16 & F1E & 121 & 0.78 & 0.99 & 1.06 \\
\hline Building $\mathrm{Co}=$ & $156 \mathrm{ppb}$ & $227 / 516$ & $\mathrm{~F} 1 \mathrm{E} / \mathrm{C} 2$ & 137 & 0.88 & 0.94 & 1.01 \\
\hline & & & \multicolumn{2}{|l|}{ Average } & 0.94 & & 0.99 \\
\hline
\end{tabular}


Table 3 Mean Local Ages of Air

\begin{tabular}{|c|c|c|c|c|c|c|c|}
\hline \multirow[b]{2}{*}{ TEST } & & \multirow[b]{2}{*}{$\begin{array}{c}\text { Room Number/ } \\
\text { Column Location }\end{array}$} & \multicolumn{4}{|c|}{ Mean Local Age of Air, $\tau$} & \multirow{2}{*}{$\begin{array}{c}\text { Local Tracer } \\
\text { Gas Decay } \\
\text { Rate from } \\
\text { Table } 2\end{array}$} \\
\hline & & & \multicolumn{2}{|c|}{$\begin{array}{l}\text { From Average } \\
\text { Concentration }\end{array}$} & \multicolumn{2}{|c|}{ From Integral } & \\
\hline \multirow{3}{*}{\multicolumn{2}{|c|}{ Monday-AM }} & $554 / M 8$ & 1.14 & 0.88 & 1.00 & 1.00 & 0.96 \\
\hline & & 616/F 12 & 1.05 & 0.95 & 1.03 & 0.97 & 0.98 \\
\hline & & $630 / N 14$ & 1.10 & 0.91 & 1.06 & 0.94 & 0.93 \\
\hline Building Air & & $630 / 16$ & 1.12 & 0.89 & 1.08 & 0.92 & 0.91 \\
\hline Exchange Rate $=$ & 0.93 ach & $642 / 44$ & 1.09 & 0.92 & 1.14 & 0.88 & 0.90 \\
\hline \multirow[t]{5}{*}{ Monday-PM } & & $301 / \mathrm{M} 5$ & 1.26 & 0.80 & 1.23 & 0.81 & 0.77 \\
\hline & & $311 / D 8$ & 1.20 & 0.83 & 1.16 & 0.86 & 0.87 \\
\hline & & $313 / 010$ & 1.18 & 0.85 & 1.14 & 0.88 & 0.89 \\
\hline & & $320 / \mathrm{D} 14$ & 1.12 & 0.89 & 1.08 & 0.93 & 0.93 \\
\hline & & $325 / \mathrm{L} 17$ & 1.04 & 0.97 & 0.99 & 1.01 & 0.97 \\
\hline Building Air & & $329 / \mathrm{T} 16$ & 1.19 & 0.84 & 1.10 & 0.91 & 0.95 \\
\hline Exchange Rate $=$ & 0.91 ach & 454/P8 & 1.06 & 0.94 & 1.05 & 0.95 & 0.92 \\
\hline \multirow[t]{5}{*}{ Tuesday-AM } & & $301 / \mathrm{M5}$ & 1.02 & 0.98 & 1.05 & 0.95 & 0.95 \\
\hline & & $454 / P 8$ & 1.01 & 0.99 & 1.03 & 0.97 & 0.97 \\
\hline & & $503 / \mathrm{K} 4$ & 1.12 & 0.89 & 1.11 & 0.90 & 0.90 \\
\hline & & $509 / D 4$ & 1.22 & 0.82 & 1.14 & 0.88 & 0.89 \\
\hline & & $509 / \mathrm{D} 6$ & 1.15 & 0.87 & 1.14 & 0.88 & 0.88 \\
\hline Building Air & & $548 / S 4$ & 1.07 & 0.93 & 1.06 & 0.94 & 0.94 \\
\hline Exchange Rate $=$ & 0.94 ach & $548 / 14$ & 1.08 & 0.92 & 1.07 & 0.94 & 0.93 \\
\hline \multirow[t]{5}{*}{ Tuesday-PM } & & $454 / P 8$ & 1.07 & 0.93 & 1.03 & 0.97 & 0.96 \\
\hline & & $502 / K 8$ & 1.11 & 0.90 & 1.09 & 0.92 & 0.93 \\
\hline & & $524 / \mathrm{K} 12$ & 1.03 & 0.97 & 1.01 & 0.99 & 0.98 \\
\hline & & $532 / R 13$ & 1.03 & 0.97 & 1.00 & 1.00 & 0.99 \\
\hline & & $537 N 14$ & 1.13 & 0.89 & 1.10 & 0.91 & 0.93 \\
\hline Building Air & & $554 / M 8$ & 1.12 & 0.89 & 1.06 & 0.95 & 0.95 \\
\hline Exchange Rate $=$ & 0.94 ach & $557 / Q 10$ & 1.03 & 0.97 & 1.01 & 0.99 & 0.97 \\
\hline \multirow[t]{5}{*}{ Wednesday-AM } & & $413 / D 10$ & 1.07 & 0.94 & 1.08 & 0.93 & 0.96 \\
\hline & & $442 / 512$ & 1.05 & 0.96 & 1.04 & 0.96 & 0.97 \\
\hline & & 444/R 10 & 1.10 & 0.91 & 1.11 & 0.90 & 0.92 \\
\hline & & 454/P8 & 1.20 & 0.83 & 1.16 & 0.86 & 0.87 \\
\hline & & 454/R8 & 1.20 & 0.84 & 1.18 & 0.85 & 0.84 \\
\hline Building Air & & 462/P 10 & 1.13 & 0.89 & 1.07 & 0.93 & 0.92 \\
\hline Exchange Rate = & 0.91 ach & 464/P 12 & 1.13 & 0.88 & 1.13 & 0.89 & 0.92 \\
\hline \multirow[t]{5}{*}{ Wednesday-PM } & & $401 / \mathrm{M} 5$ & 1.11 & 0.90 & 1.13 & 0.89 & 0.91 \\
\hline & & $405 / J 4$ & 1.16 & 0.86 & 1.14 & 0.88 & 0.87 \\
\hline & & $443 \times 11$ & 1.11 & 0.90 & 1.11 & 0.90 & 0.90 \\
\hline & & $447 N 8$ & 1.12 & 0.89 & 1.11 & 0.90 & 0.88 \\
\hline & & $449 N 4$ & 1.06 & 0.94 & 1.08 & 0.93 & 0.90 \\
\hline Building Air & & 449 N5 & 1.13 & 0.89 & 1.08 & 0.92 & 0.91 \\
\hline Exchange Rate = & 0.94 ach & $454 / \mathrm{P} 8$ & 1.09 & 0.92 & 1.07 & 0.94 & 0.93 \\
\hline \multicolumn{2}{|l|}{ Thursday-AM } & $119 / \mathrm{H} 17$ & 1.14 & 0.87 & 1.13 & 0.89 & 0.92 \\
\hline & & 135 W8 & 1.12 & 0.89 & 1.15 & 0.87 & 0.86 \\
\hline Building Air & & $138 / \times 5$ & 1.15 & 0.87 & 1.16 & 0.86 & 0.86 \\
\hline Exchange Rate = & 0.90 ach & 454/P8 & 1.12 & 0.89 & 1.12 & 0.90 & 0.88 \\
\hline Thursday-PM & & $309 / 65$ & 1.26 & 0.80 & 1.19 & 0.84 & 0.84 \\
\hline & & $311 / E 9$ & 1.23 & 0.81 & 1.19 & 0.84 & 0.86 \\
\hline & & $320 / G 17$ & 1.11 & 0.90 & 1.07 & 0.93 & 0.95 \\
\hline & & $324 / G 11$ & 1.12 & 0.89 & 1.09 & 0.92 & 0.93 \\
\hline & & $331 / \pi 17$ & 1.12 & 0.90 & 1.13 & 0.88 & 0.91 \\
\hline Building Air & & 409/E7 & 1.14 & 0.88 & 1.13 & 0.88 & 0.89 \\
\hline Exchange Rate $=$ & 0.90 ach & $454 / \mathrm{PB}$ & 1.25 & 0.80 & 1.19 & 0.84 & 0.83 \\
\hline Friday-AM & & $105 / K_{4}$ & 1.13 & 0.88 & 1.12 & 0.89 & 0.91 \\
\hline & & 209/E 7 & 1.21 & 0.82 & 1.18 & 0.84 & 0.84 \\
\hline & & $209 / D 4$ & 1.28 & 0.78 & 1.22 & 0.82 & 0.82 \\
\hline Building Air & & $235 / 10$ & 1.12 & 0.89 & 1.10 & 0.91 & 0.92 \\
\hline Exchange Rate $=$ & 0.92 ach & $454 / \mathrm{PB}$ & 1.20 & 0.83 & 1.12 & 0.90 & 0.90 \\
\hline Friday-PM & & 215/E12 & 1.06 & 0.95 & 1.03 & 0.97 & 0.98 \\
\hline & & $219 / \mathrm{C} 16$ & 1.07 & 0.94 & 1.04 & 0.96 & 0.98 \\
\hline & & 219/E 18 & 1.06 & 0.94 & 1.03 & 0.97 & 0.97 \\
\hline & & $221 / G 16$ & 1.11 & 0.90 & 1.07 & 0.94 & 0.95 \\
\hline & & $222 / K 14$ & 0.99 & 1.01 & 0.94 & 1.07 & 1.03 \\
\hline Building Air & & $227 / P_{16}$ & 1.05 & 0.96 & 1.01 & 0.99 & 0.99 \\
\hline Exchange Rate $=$ & 0.93 ach & $227 / S 16$ & 1.17 & 0.85 & 1.11 & 0.90 & 0.94 \\
\hline
\end{tabular}




\section{Table 4 Summary of Local Ages of Air}

\begin{tabular}{|c|c|c|c|c|c|c|}
\hline \multirow[b]{2}{*}{ TEST } & & \multicolumn{4}{|c|}{ Mean Local Age of Air, $\tau$} & \multirow{2}{*}{$\begin{array}{c}\text { Local Tracer } \\
\text { Gas Decay } \\
\text { Rate from } \\
\text { Table } 2\end{array}$} \\
\hline & & \multicolumn{2}{|c|}{$\begin{array}{l}\text { From Average } \\
\text { Concentration }\end{array}$} & \multicolumn{2}{|c|}{ From Integral } & \\
\hline \multirow[t]{2}{*}{ Monday-AM } & Average & 1.10 & 0.91 & 1.06 & 0.94 & 0.94 \\
\hline & Standard Deviation & 0.03 & 0.03 & 0.05 & 0.05 & 0.03 \\
\hline \multirow[t]{2}{*}{ Monday-PM } & Average & 1.15 & 0.87 & 1.11 & 0.91 & 0.90 \\
\hline & Standard Deviation & 0.08 & 0.06 & 0.08 & 0.06 & 0.07 \\
\hline \multirow[t]{2}{*}{ Tuesday-AM } & Average & 1.10 & 0.92 & 1.09 & 0.92 & 0.92 \\
\hline & Standard Deviation & 0.07 & 0.06 & 0.04 & 0.04 & 0.03 \\
\hline \multirow[t]{2}{*}{ Tuesday-PM } & Average & 1.07 & 0.93 & 1.04 & 0.96 & 0.96 \\
\hline & Standard Deviation & 0.05 & 0.04 & 0.04 & 0.04 & 0.02 \\
\hline \multirow[t]{2}{*}{ Wednesday-AM } & Average & 1.12 & 0.89 & 1.11 & 0.90 & 0.91 \\
\hline & Standard Deviation & 0.06 & 0.05 & 0.05 & 0.04 & 0.04 \\
\hline \multirow[t]{2}{*}{ Wednesday-PM } & Average & 1.11 & 0.90 & 1.10 & 0.91 & 0.90 \\
\hline & Standard Deviation & 0.03 & 0.03 & 0.03 & 0.02 & 0.02 \\
\hline \multirow[t]{2}{*}{ Thursday-AM } & Average & 1.13 & 0.88 & 1.14 & 0.88 & 0.88 \\
\hline & Standard Deviation & 0.02 & 0.01 & 0.02 & 0.01 & 0.03 \\
\hline \multirow[t]{2}{*}{ Thursday-PM } & Average & 1.17 & 0.85 & 1.14 & 0.88 & 0.89 \\
\hline & Standard Deviation & 0.07 & 0.05 & 0.05 & 0.04 & 0.05 \\
\hline \multirow[t]{2}{*}{ Friday-AM } & Average & 1.19 & 0.84 & 1.15 & 0.87 & 0.88 \\
\hline & Standard Deviation & 0.07 & 0.05 & 0.05 & 0.04 & 0.04 \\
\hline \multirow[t]{2}{*}{ Friday-PM } & Average & 1.07 & 0.94 & 1.03 & 0.97 & 0.98 \\
\hline & Standard Deviation & 0.06 & 0.05 & 0.05 & 0.05 & 0.03 \\
\hline \multirow[t]{2}{*}{ All Tests } & Average & 1.12 & 0.90 & 1.09 & 0.92 & 0.92 \\
\hline & Standard Deviation & 0.07 & 0.05 & 0.06 & 0.05 & 0.05 \\
\hline
\end{tabular}


Table 5 Local Carbon Dioxide Concentrations

\begin{tabular}{|c|c|c|c|c|}
\hline TEST & & $\begin{array}{r}\text { Room Number/ } \\
\text { Column Location }\end{array}$ & $\begin{array}{l}\text { Local } \\
\text { Concentration }\end{array}$ & $\frac{\text { Local Concentration }}{\text { Building Concentration }}$ \\
\hline \multirow[t]{3}{*}{ Monday-AM } & $8: 30-10: 30$ & $554 / \mathrm{M} 8$ & 494 & 1.12 \\
\hline & & $616 / F 12$ & 528 & 1.19 \\
\hline & & $630 / N 14$ & 489 & 1.11 \\
\hline Building Average & & $630 / N 16$ & 495 & 1.12 \\
\hline Concentration = & 442 ppm & $642 / \mathrm{U} 4$ & 476 & 1.08 \\
\hline \multirow[t]{5}{*}{ Monday-PM } & $13: 30-15: 30$ & $301 / \mathrm{M}$ & 527 & 1.10 \\
\hline & & $311 / D 8$ & 516 & 1.08 \\
\hline & & 313/D10 & 497 & 1.04 \\
\hline & & 320/D14 & 498 & 1.04 \\
\hline & & 325/L17 & 497 & 1.04 \\
\hline Building Average & & $329 / 116$ & 514 & 1.08 \\
\hline Concentration = & $477 \mathrm{ppm}$ & $454 / P B$ & 549 & 1.15 \\
\hline \multirow[t]{5}{*}{ Tuesday-AM } & $8: 30-10: 30$ & $301 / \mathrm{M} 5$ & 473 & 1.01 \\
\hline & & 454/P8 & 548 & 1.17 \\
\hline & & $503 / K 4$ & 520 & 1.11 \\
\hline & & $509 / D 4$ & 486 & 1.04 \\
\hline & & 509/D6 & 486 & 1.04 \\
\hline Building Average & & $548 / S 4$ & 512 & 1.09 \\
\hline Concentration $=$ & $468 \mathrm{ppm}$ & $548 / \mathrm{U} 4$ & 490 & 1.05 \\
\hline \multirow{5}{*}{ Tuesday-PM } & $13: 30-15: 30$ & $454 / P 8$ & 593 & 1.18 \\
\hline & & $502 / K 8$ & 544 & 1.08 \\
\hline & & $524 / K 12$ & 518 & 1.03 \\
\hline & & 532/R13 & 519 & 1.03 \\
\hline & & $537 / N 14$ & 563 & 1.12 \\
\hline Building Average & & $554 / \mathrm{MB}$ & 559 & 1.11 \\
\hline Concentration = & 503 ppm & $557 / 010$ & 554 & 1.10 \\
\hline \multirow[t]{5}{*}{ Wednesday-AM } & $8: 30-10: 30$ & $413 / 010$ & 513 & 1.02 \\
\hline & & $442 / 512$ & 536 & 1.07 \\
\hline & & 444/R10 & 523 & 1.04 \\
\hline & & $454 / P 8$ & 549 & 1.09 \\
\hline & & $454 / R 8$ & 553 & 1.10 \\
\hline Building Average & & 462/P10 & 504 & 1.00 \\
\hline Concentration = & 502 ppm & 464/P12 & 519 & 1.03 \\
\hline \multirow[t]{5}{*}{ Wednesday-PM } & $13: 30-15: 30$ & $401 / \mathrm{M} 5$ & 545 & 1.07 \\
\hline & & $405 / J 4$ & 536 & 1.06 \\
\hline & & $443 / W 11$ & 539 & 1.06 \\
\hline & & $447 N 8$ & 545 & 1.07 \\
\hline & & 449 N4 & 567 & 1.12 \\
\hline \multirow{2}{*}{$\begin{array}{l}\text { Building Average } \\
\text { Concentration = }\end{array}$} & & 449 W5 & 542 & 1.07 \\
\hline & $507 \mathrm{ppm}$ & 454/P8 & 511 & 1.01 \\
\hline \multirow[t]{2}{*}{ Thursday-AM } & $8: 30-10: 30$ & $119 / \mathrm{H} 17$ & 462 & 0.97 \\
\hline & & 135/WB & 473 & 0.99 \\
\hline \multirow{2}{*}{$\begin{array}{l}\text { Building Average } \\
\text { Concentration = }\end{array}$} & & $138 / \times 5$ & 491 & 1.03 \\
\hline & 477 ppm & 454/P8 & 513 & 1.08 \\
\hline \multirow[t]{5}{*}{ Thursday-PM } & $13: 30-15: 30$ & $309 / \mathrm{G5}$ & 493 & 0.95 \\
\hline & & 311/E9 & 515 & 0.99 \\
\hline & & 320/G17 & 546 & 1.05 \\
\hline & & 324/G11 & 556 & 1.07 \\
\hline & & $331 / \pi 17$ & 512 & 0.98 \\
\hline \multirow{2}{*}{$\begin{array}{l}\text { Building Average } \\
\text { Concentration = }\end{array}$} & & 409/E7 & 561 & 1.08 \\
\hline & 521 ppm & 454/P8 & 603 & 1.16 \\
\hline \multirow[t]{3}{*}{ Friday-AM } & $8: 30-10: 30$ & $105 / K^{4}$ & 493 & 1.01 \\
\hline & & 209/E7 & 512 & 1.05 \\
\hline & & 209/D4 & 499 & 1.02 \\
\hline Building Average & & $235 / N 10$ & 483 & 0.99 \\
\hline Concentration $=$ & $488 \mathrm{ppm}$ & $454 / P 8$ & 518 & 1.06 \\
\hline \multirow[t]{5}{*}{ Fnday-PM } & $13: 30-15: 30$ & 215/E12 & 524 & 1.00 \\
\hline & & $219 / C 16$ & 537 & 1.03 \\
\hline & & 219/E 18 & 527 & 1.01 \\
\hline & & $221 / G 16$ & 533 & 1.02 \\
\hline & & $222 / K 14$ & 535 & 1.02 \\
\hline & & 227/P 16 & 510 & 0.98 \\
\hline \multirow{3}{*}{ Concentration = } & 522 ppm & $227 / S 16$ & 524 & 1.00 \\
\hline & & Average & 521 & 1.06 \\
\hline & & Standard Devia & 29 & 0.05 \\
\hline
\end{tabular}


Table 6 Weekly Air Exchange Rates and Carbon Dioxide Concentrations

\begin{tabular}{|c|c|c|}
\hline Week Starting & $\begin{array}{c}\text { Average Air } \\
\text { Exchange Rate } \\
\text { (ach) }\end{array}$ & $\begin{array}{c}\text { Average Peak Carbon } \\
\text { Dioxide Concentration } \\
\text { (ppm) }\end{array}$ \\
\hline 30-Jan-89 & 0.86 & "** \\
\hline $\begin{array}{c}\text { 6-Feb-89 } \\
\text { 13-Feb-89 } \\
20-F e b-89 \\
\text { 27-Feb-89* }\end{array}$ & $\begin{array}{l}0.85 \\
0.85 \\
0.87 \\
0.90\end{array}$ & $\begin{array}{c}* * \\
* * \\
* * \\
516\end{array}$ \\
\hline $\begin{array}{c}\text { 6-Mar-89 } \\
\text { 13-Mar-89 } \\
\text { 20-Mar-89 } \\
\text { 27-Mar-89 }\end{array}$ & $\begin{array}{c}* * \\
0.88 \\
0.86 \\
0.89\end{array}$ & $\begin{array}{l}505 \\
517 \\
520\end{array}$ \\
\hline $\begin{array}{l}\text { 3-Apr-89 } \\
\text { 17-Apr-89 }\end{array}$ & $\begin{array}{l}0.90 \\
0.94\end{array}$ & ** \\
\hline $\begin{array}{l}\text { 22-May-89 } \\
29-\text { Маy-89 }\end{array}$ & $\begin{array}{l}0.87 \\
0.82\end{array}$ & "** \\
\hline $\begin{array}{l}\text { 12-Jun-89 } \\
\text { 19-Jun-89 } \\
\text { 26-Jun-89 }\end{array}$ & $\begin{array}{c}0.87 \\
* *\end{array}$ & $\begin{array}{l}510 \\
516 \\
504\end{array}$ \\
\hline $\begin{array}{r}26-J u l-89 \\
31-J u l-89 \\
\end{array}$ & $\begin{array}{l}0.82 \\
0.84 \\
\end{array}$ & $* *$ \\
\hline
\end{tabular}



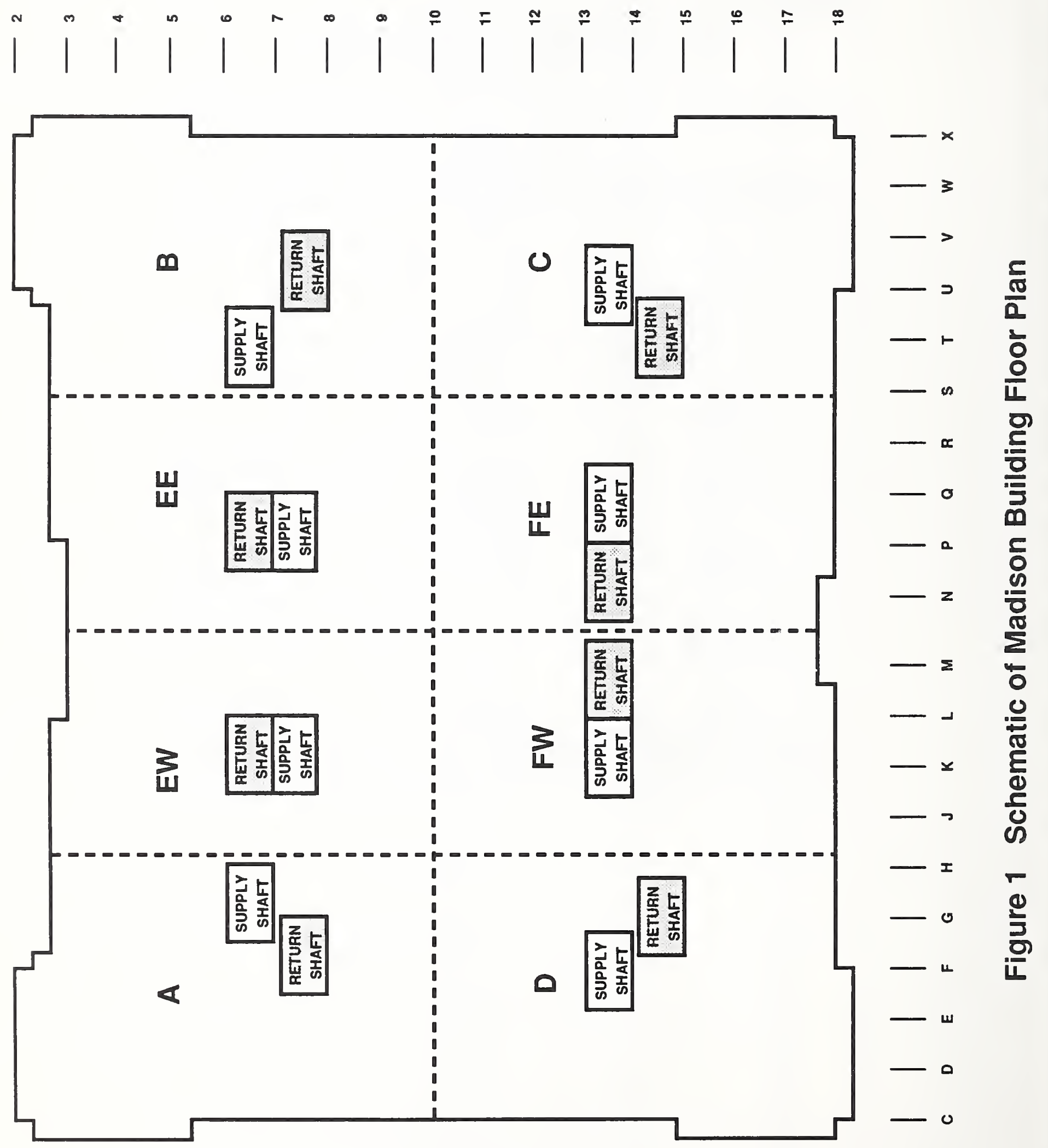


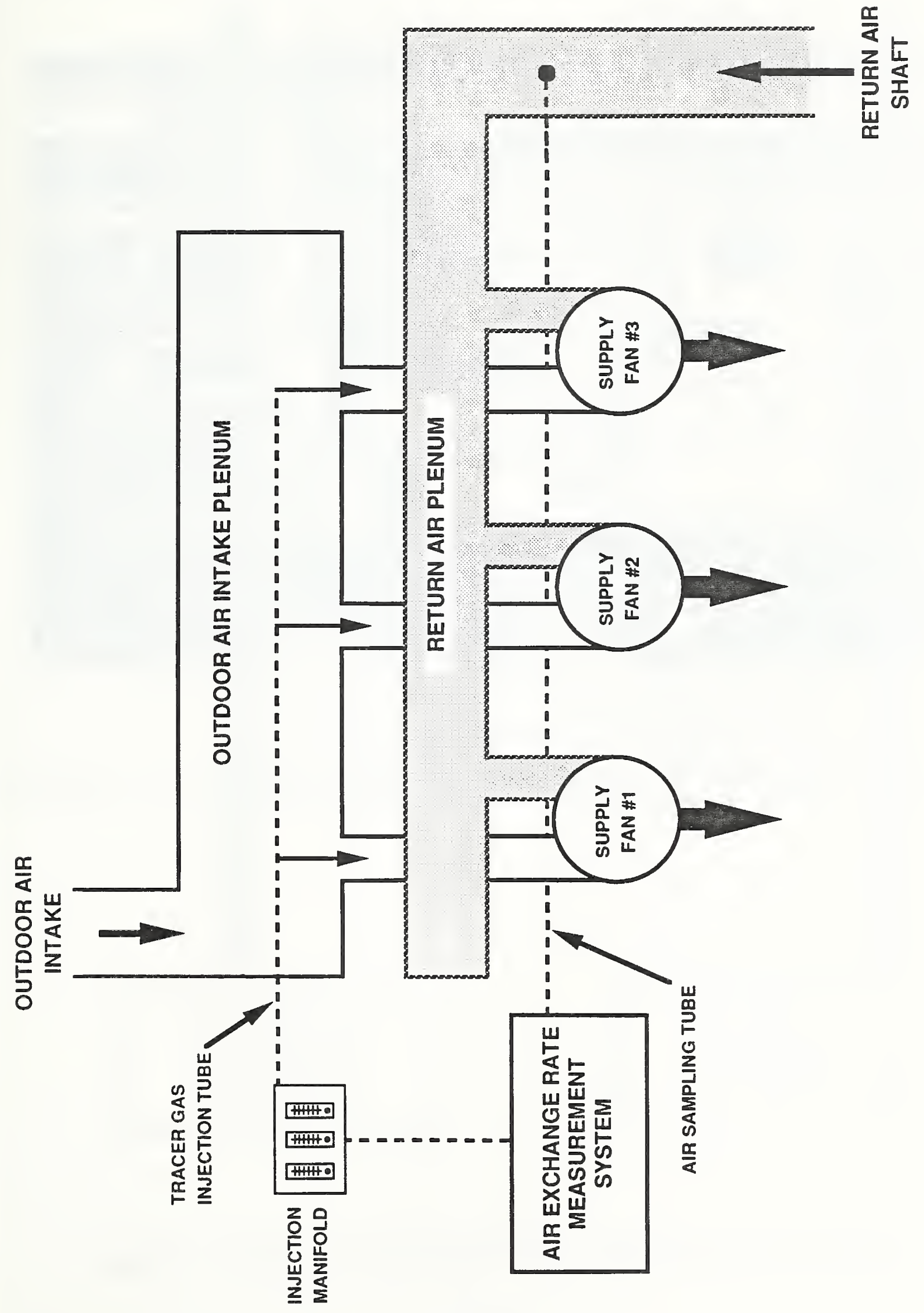

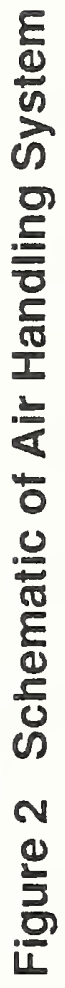




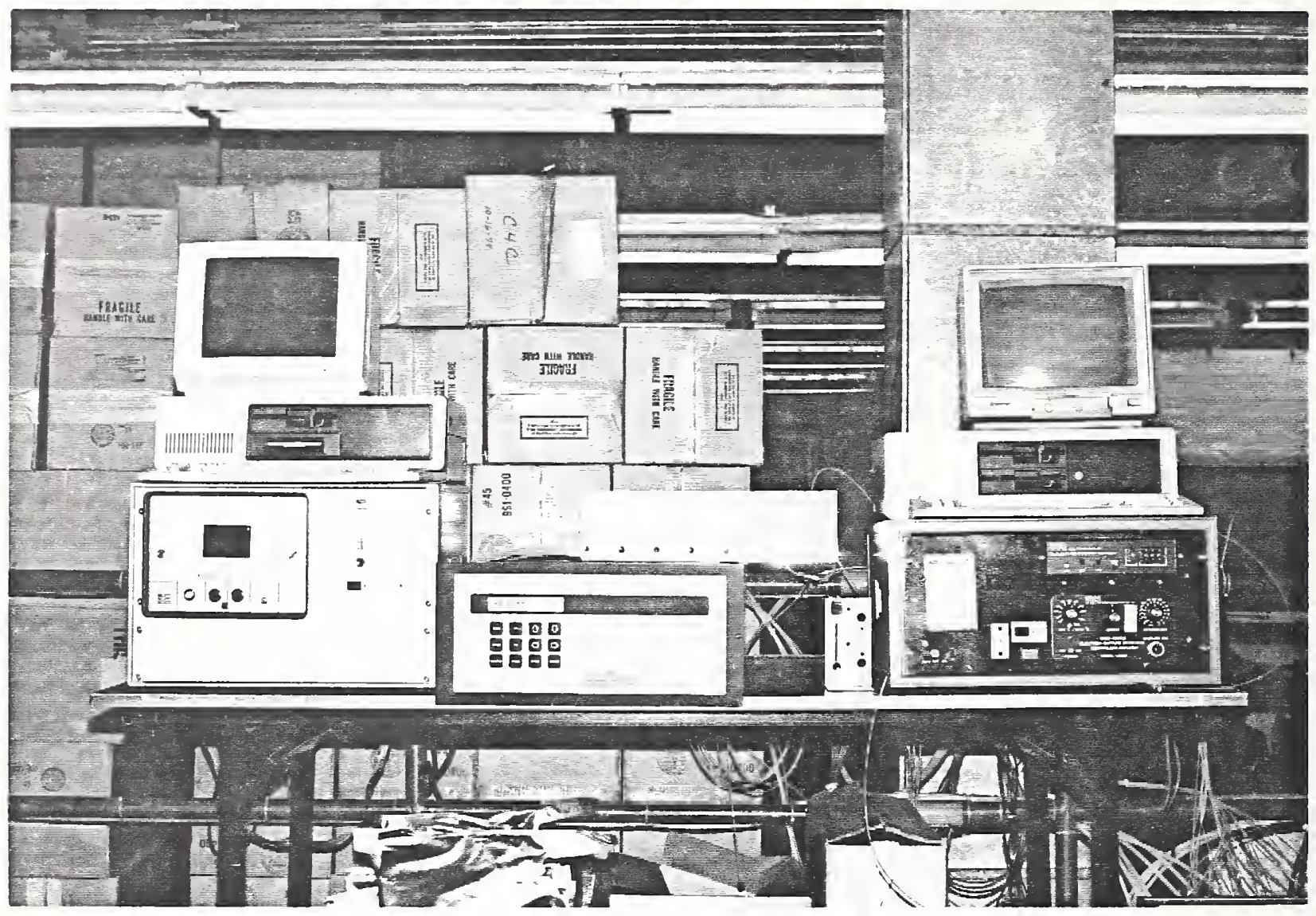

Figure 3 Photograph of Tracer Gas and Contaminant Measurement System 


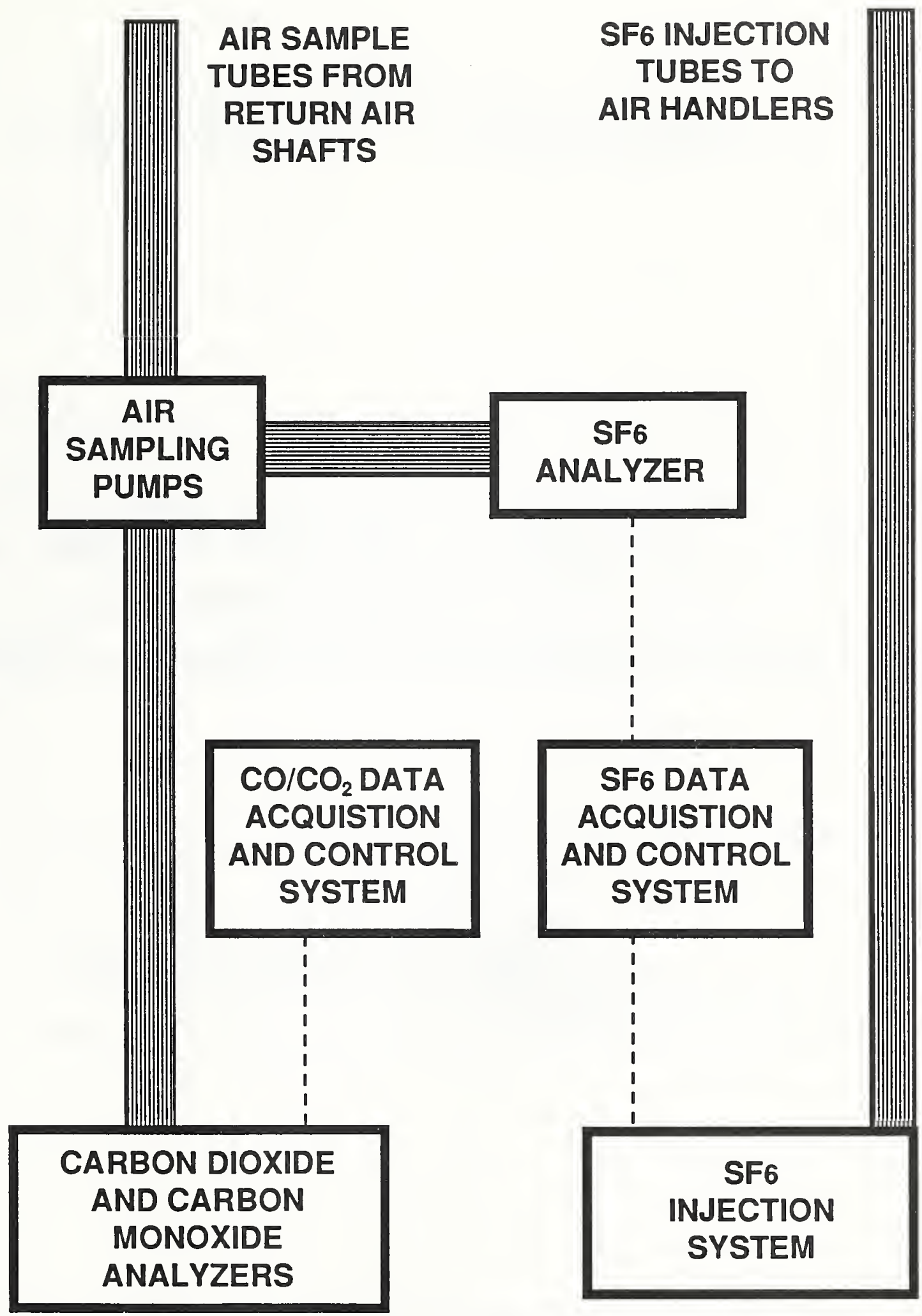

Figure 4 Schematic of $\mathrm{SF}_{6}$ and $\mathrm{CO} / \mathrm{CO}_{2}$ Measurement System 


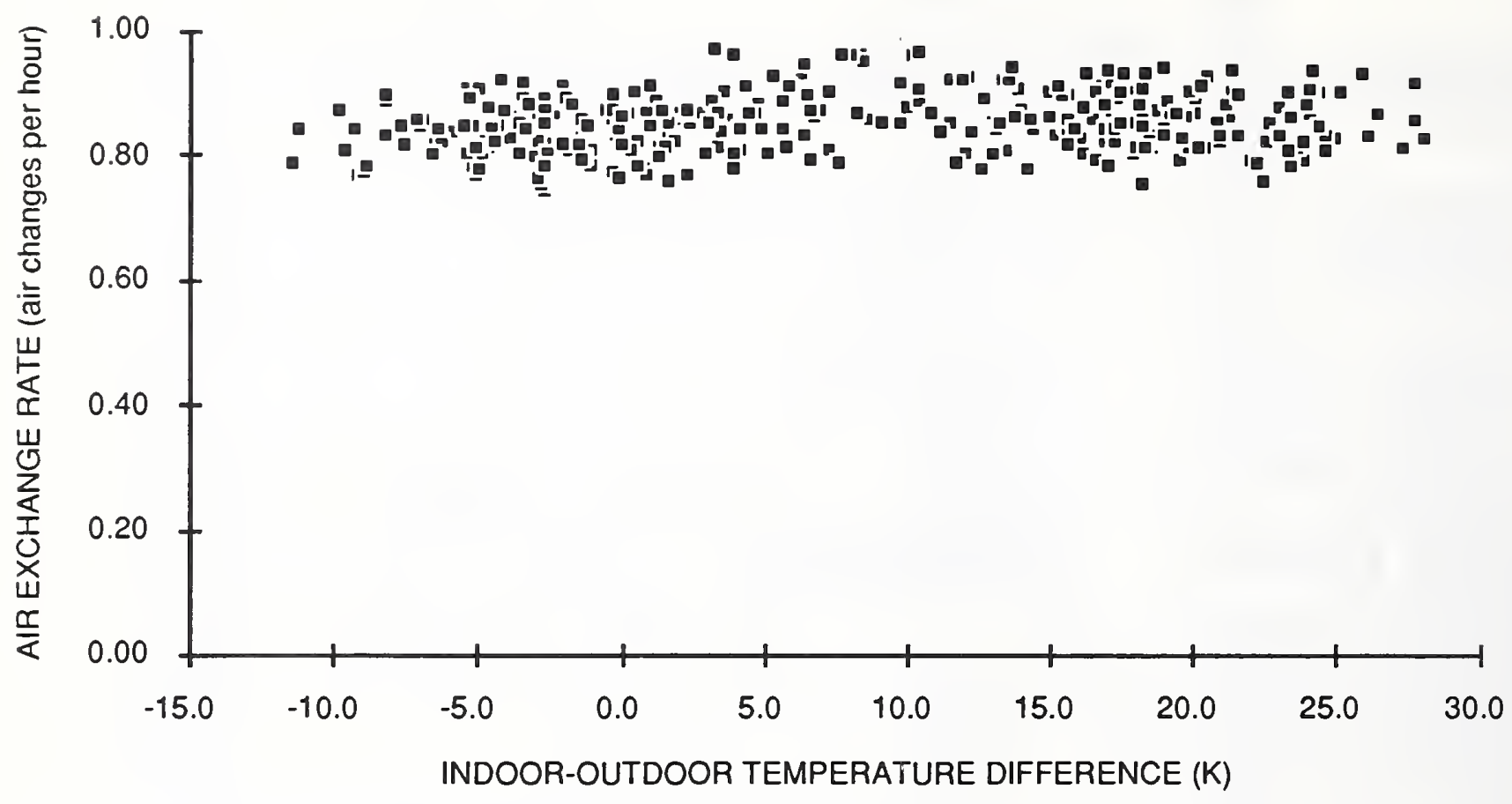

Figure 5 Daytime Air Exchange Rates versus Temperature Difference

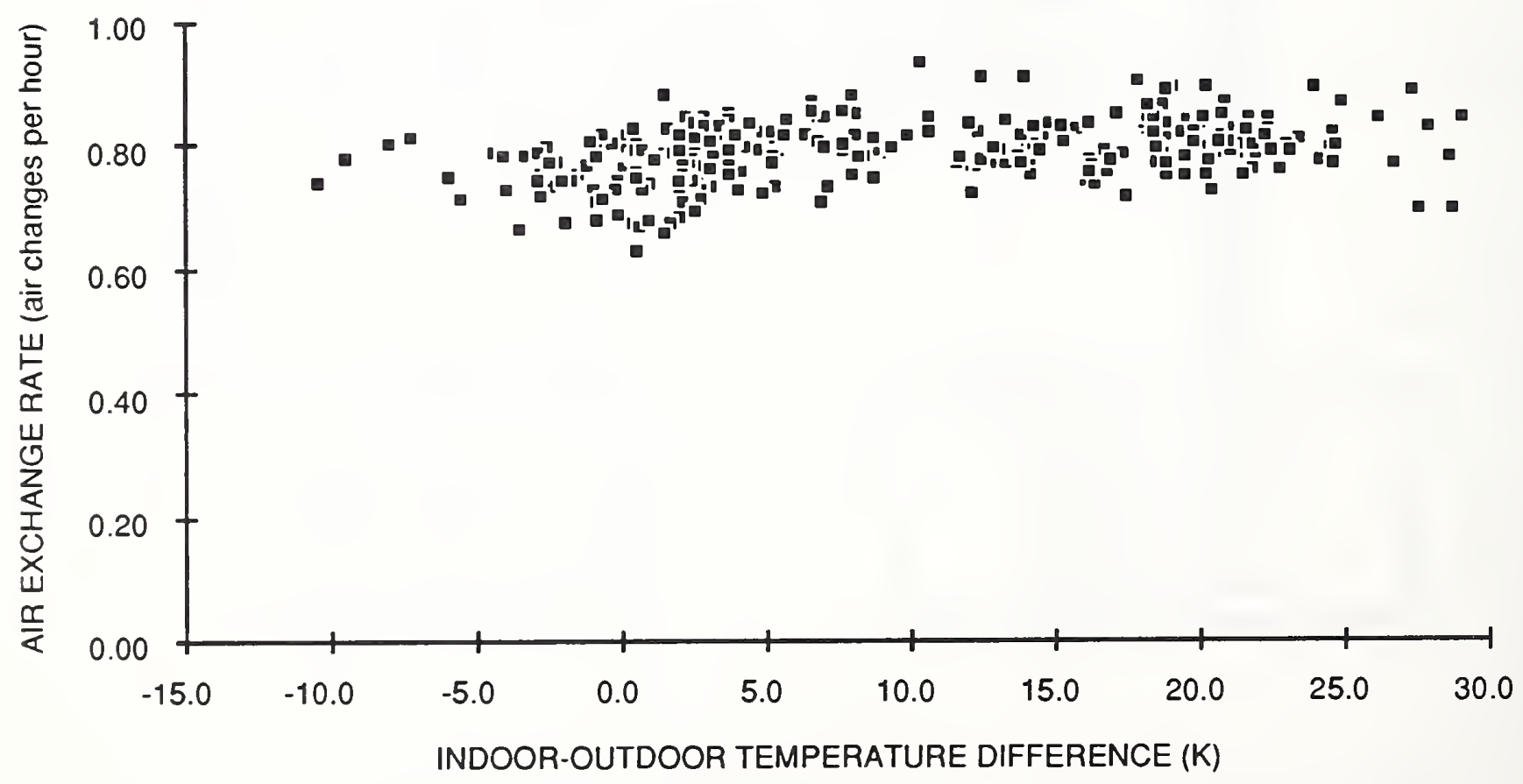

Figure 6 Nighttime Air Exchange Rates versus Temperature Difference 


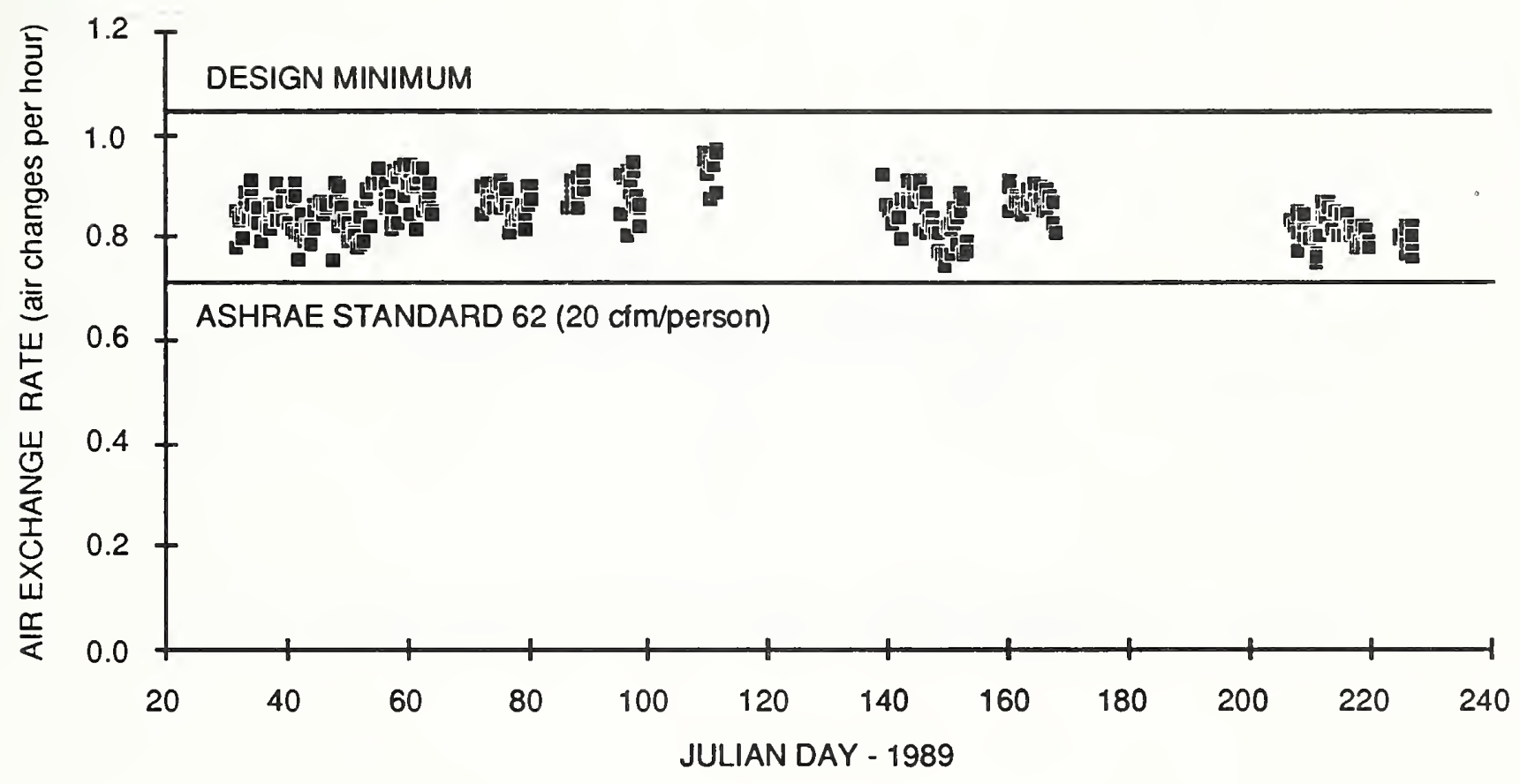

Figure 7 Daytime Air Exchange Rate versus Julian Day 


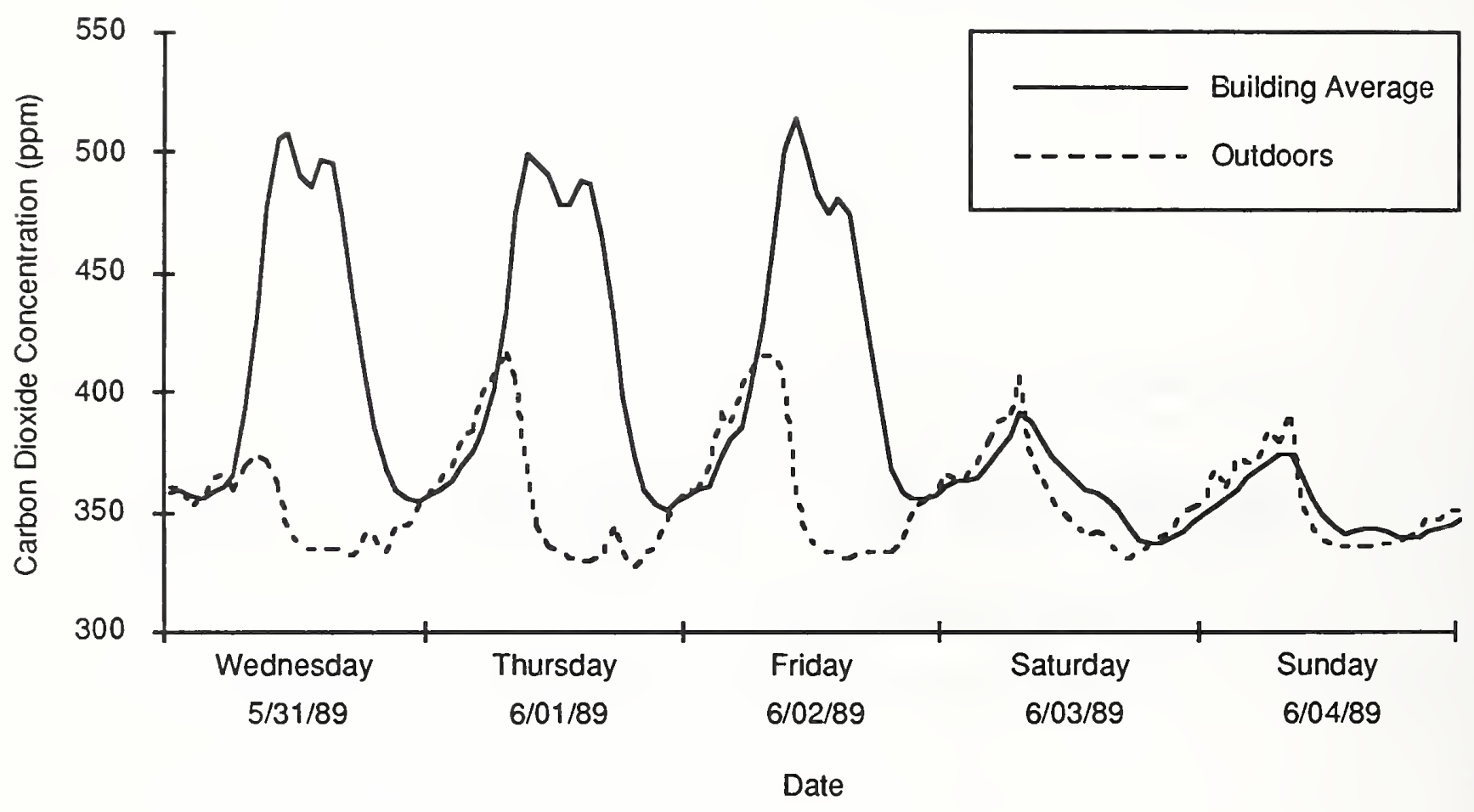

Figure 8 Example of Carbon Dioxide Concentration Data 


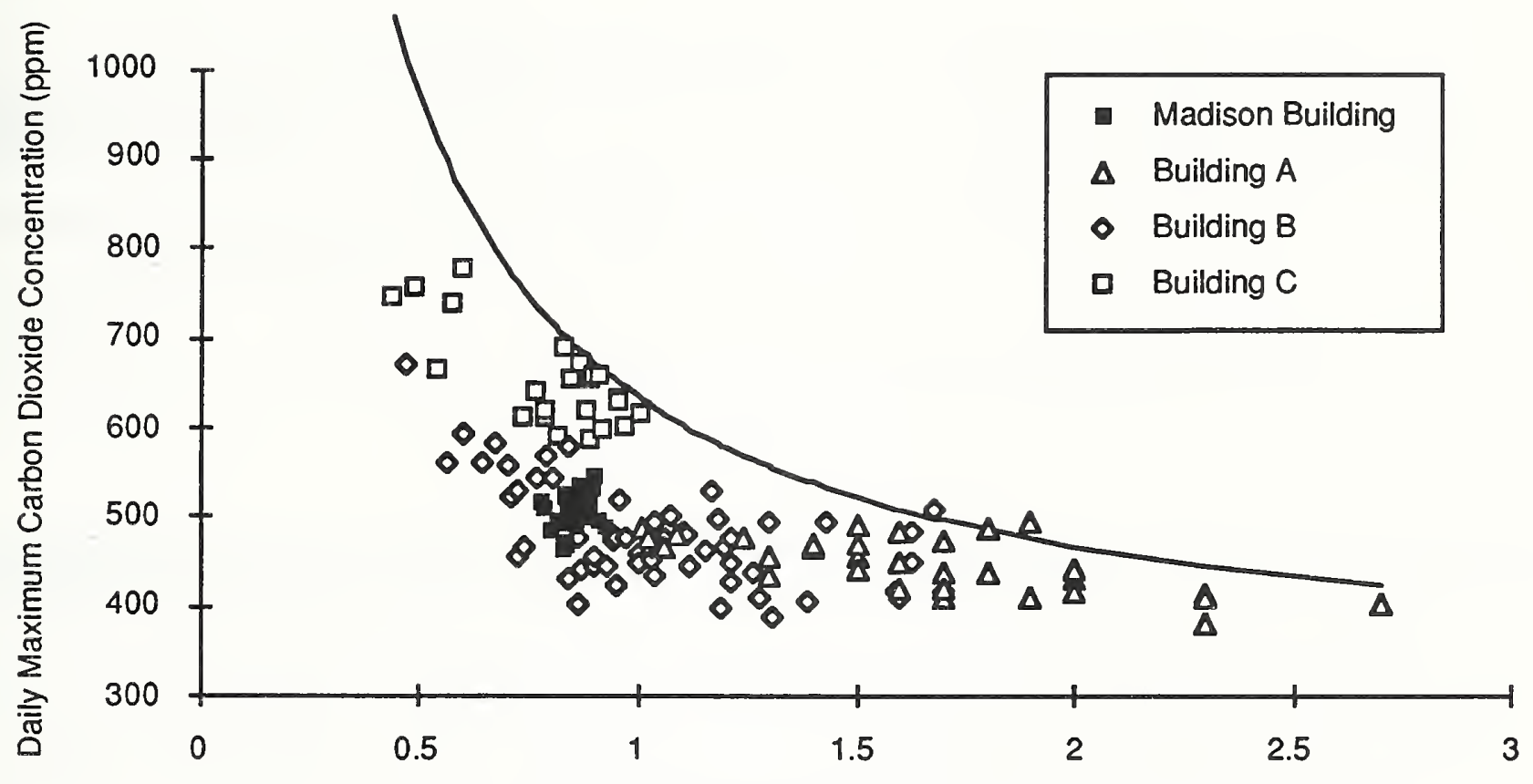

Daily Average Air Exchange Rate (ach)

Figure 9 Maximum Carbon Dioxide Concentration versus Air Exchange Rate 


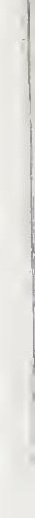




\begin{tabular}{|c|c|c|}
\hline \multirow[t]{4}{*}{$\begin{array}{l}\text { MIST.1144 } \\
\text { (REV. 3-0D) }\end{array}$} & \multirow{4}{*}{$\begin{array}{l}\text { U.S. DEPARTMENT OF COMMEACE } \\
\text { NATIONAL INSTITUTE OF STANDARDS AND TECHNOLOGY } \\
\text { BIBLIOGRAPHIC DATA SHEET }\end{array}$} & 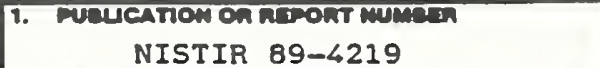 \\
\hline & & 2 FENFORMLNO ORCWMEATIOM AEPORT MUALES \\
\hline & & 2 MUDUCATIOMDATE \\
\hline & & DECEMBER 1989 \\
\hline
\end{tabular}

4. TIIE AMD SUDTrTE

Ventilation and Air Quality Investigation of the Madison Bullding Phase I Report

5. Autron(\$)

Andrew K. Persily, W. Stuart Dols

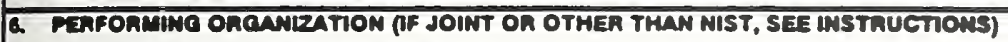

U.S. DEPARTMENT OF COMmEnCE

MATOMAL WNSTIUUTH OF STANDARDS AND TECHNOLOQY

9. SPONSOAIMO ORQWMIZATION MAME AND COMPLETE ADDAESS (STRET, GT, STATE, ZIF)

U.S. Department of Energy

Nashington, DC

10. SUFPLEMENTARY NOTES

DOCUMEAT DESCRIEES A COMPUTER PROORAM; SF-1ES, FIPS SOFTWARE SUMMMAY, IS ATTACMED.

11. AOSTRACT IA 2OO-WOAD OA LESS FACTUAL SUMMAAY OF MOST SIOMIFICANT IMFOAMATOM. DOCUMEMT INCLUOES SIOMIFICAMT EIBUOORAPHY OR UTERATURE SURVEY, MENTION IT HERE,

The National Institute of Standards and Technology (NIST, formerly the National Bureau of Standards) is conducting a long-term study of ventilation and air quality in the Madison Building of the Library of Congress. This investigation, which is being sponsored by the U.S. Department of Energy, began in late 1988 and will continue into 1990. NIST is conducting continuous measurements of whole building air exchange rates, as well as periodic measurements of local ventilation characteristics and indoor levels of carbon dioxide, carbon monoxide, respirable particulates, radon and radon progeny, and volatile organic compounds. During the first phase of the study, NIST has measured whole building air exchange rates, local air exchange characteristics, and indoor concencrations of carbon dioxide and carbon monoxide. This report presents the techniques used to make these measurements and the results that have been obtained as of September 1989. These results indicate that the whole building air exchange rate is relatively constant over time and that the ventilation air is well distributed throughout the building. The measured air exchange rates are slightly above the minimum recommended levels contained in ASHRAE Standard 62-1989 and slightly below the mechanical ventilation system's design value for the outdoor air intake rate. The measured levels of carbon dioxide and carbon monoxide are low relative to the recomended values contained in this same ventilaticn standard.

12. KEY WORDS 16 TO 12 ENTAIES; ALPHABETICAL ORDER; CAPITALEE OMLY FROFER MAMES; ND SEPARATE KEY WORDS OY SEMICOLONS)

Air exchange, carbon dioxide, indoor air quality, mechanical ventilation, office building. tracer gas, ventilatior, ventilation effectiveness

13 avallasiutr

UNUMTED

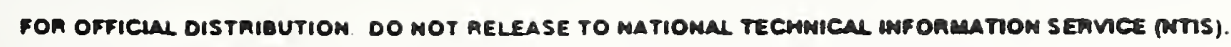

OROER FROM SUPERINTEMOENT OF DOCUMEMTS. U.S. OOVERMMENT FAIMTIMO OFFICE WASMINOTON. DC ZOMOZ.

OROEH FROM MATIONAL TECMNICAL INF ORMATION SERVCE (MTIS). SPRINOFTEL.VA 20161.

\begin{tabular}{|l} 
14. MUMBEA OF PAINTED PAQES \\
37 \\
15. PAICE \\
$\$ 12.95$
\end{tabular}

\section{ELECTRONIC FORM}




